\title{
Erkek Okul Öncesi Eğitimi Öğretmenlerinin Yașadığı Mesleki Sorunlar
}

\author{
Öğretmen Ali Er ${ }^{1}$ \\ Doç. Dr. Hüseyin Ergen ${ }^{2 *}$
}

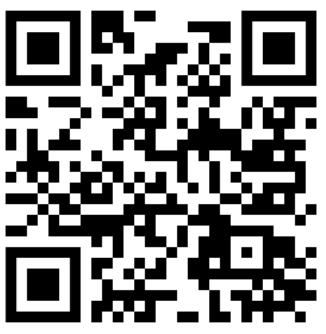

Geliş tarihi: 21.09.2020

Kabul tarihi: 17.11.2020

\section{Atıf bilgisi:}

IBAD Sosyal Bilimler Dergisi

Sayı: Özel Sayı Sayfa: 359-383

Yıl: 2020

This article was checked by iThenticate Similarity Index 13\%

Bu makalede araştırma ve yayın etiğine uyulmuştur.

${ }^{1}$ Mersin Üniversitesi, Türkiye, alier42@hotmail.com ORCID ID 0000-0002-4170-6961

${ }^{2}$ Mersin Üniversitesi, Türkiye, ergen@mersin.edu.tr ORCID ID 0000-0002-2611-1863

* Sorumlu yazar öz

$\mathrm{Bu}$ araştırmada devlet okul öncesi eğitim kurumlarında çalı̧̧an erkek okul öncesi eğitimi öğretmenlerinin karșılaștığı sorunların ortaya konulması amaçlanmıștır. Katılımcıların cinsiyet, yaş, medeni durum, kıdem yılı, mezuniyeti, çalıştığı yaş grupları ve okul türü de bu amaç doğrultusunda değerlendirilmektedir. Yapılan çalışma erkek okul öncesi eğitimi öğretmenlerinin sorun tanımlamalarını tarama araștırma deseni ile belirlemeyi amaçlamaktadır. Araştırmanın evrenini Mersin ili Toroslar ilçesinde devlete bağlı okul öncesi eğitim kurumlarında görev yapmakta olan 263 okul öncesi eğitim öğretmenleri oluşturmuştur. Örneklemi; bu evrende ulaşılabilen tüm bireyler olușturmuş olup evrenin \%90'ına ulașıllmıștır. Araștırma, Toroslar'da kamuya bağlı anasınıfı ve bağımsız anaokullarında çalışan 236 öğretmenle yapılmıstır. Veri toplama sürecinde önce araștırmacılar tarafindan geliştirilen okul öncesi öğretmenleri için yarı yapılandırılmış "Öğretmen Görüşme Formu” kullanılmıș, 5 erkek 5 kadın öğretmene uygulanmıștır. Görüșmelerden ve literatür taramasından elde edilen bilgilerle erkek okul öncesi öğretmenlerinin sorunları belirlenmiş ve bir anket formu oluşturulmuştur. Oluşturulan anket formu 10 öğretmen üzerinde uygulanarak anket ile ilgili genel bir geri dönüt bildirimi alınmıştır. Geri dönütlere göre tekrar anket üzerinde düzeltmeler yapılmış daha sonra 5 uzman görüșü de alınarak anket maddeleri belirlenmiștir. Araștırma sonunda elde edilen verilere göre öğretmenler genel olarak; teneffüs ihtiyaçlarını, ikili öğretimdeki sabah ve öğleye öğrencilerin dengesiz dağılım durumlarını, velilerin okul öncesi eğitim hakkında yeterli bilgiye sahip olmamalarını, öğretmenler arasında kıyaslama yapmalarını, velilerin okul öncesi eğitimi kadın işi olarak görmelerini ve velilerin okul öncesi eğitimi bakım hizmeti olarak görmelerini sorun olarak gördükleri belirlenmiştir.

Anahtar Kelimeler: Okul Öncesi Eğitim, Erkek Okul Öncesi Öğretmeni, Okul Öncesi Eğitim Sorunları. 


\title{
Professional Problems Encountered by Male Preschool Teachers
}

\author{
Teacher Ali Er ${ }^{1^{*}}$ \\ Assoc. Prof. Dr. Hüseyin Ergen ${ }^{2}$
}

First received: 21.09 .2020

Accepted: 17.11.2020

\section{Citation:}

IBAD Journal of Social Sciences

Issue: Special Issue Pages: 359-383

Year: 2020

This article was checked by iThenticate. Similarity Index 13\%

${ }^{1}$ Mersin Üniversity, Turkey,
ali_er42@hotmail.com
ORCID ID 0000-0002-4170-6961

${ }^{2}$ Mersin Üniversitesi, Turkey, ergen@mersin.edu.tr

ORCID ID 0000-0002-2611-1863

* Corresponding Author

\begin{abstract}
In this research, it is aimed to reveal the problems of male teachers who work at public preschool institutions. Participants' age, gender, marital status, seniority year, graduations, age groups they work and the school types are also evaluated in accordance with this purpose. The study is aimed to define the male preschool teachers' problems with survey research pattern. 263 preschool teachers who work at public preschool institutions in Toroslar district of Mersin province comprise the universe of the research. All of the individuals who could be reached in this universe composed the sampling and \%90 of the universe was reached. The research was done with 236 teachers who work at state bound nursery schools and independent nursery schools in Toroslar. In data collection process, firstly, a semi-structured teacher interview form which was developed by researchers for the preschool was used and applied to 5 male teachers and 5 female teachers. Referring to literature revive and interviews, problems encountered by male preschool teachers were determined and a survey was composed. By applying the survey forms on 10 teachers, general feedback was received. According to feedbacks, corrections were done on the survey, after words by the help of 5 professional opinions survey items were created. According to the data obtained after research; teachers generally consider the need of break, unbalanced dispersion of students in dual education, parents' insufficient information about preschool education, parent's comparisons among teachers, their views about preschool education as women's work and maintenance service as a problem.
\end{abstract}

Key words: Preschool Education, Male Preschool Teacher, Preschool Education Problems 


\section{GİRIŞ}

Okul öncesi dönem çocuğun gelişiminin ve öğrenmesinin en hızlı olduğu dönemdir. Eğitimciler ve psikologlar ilk altı yaşın bireyin dil, bilişsel, sosyal, fiziksel, ruhsal ve yaratıcılık gelişimi açısından önemli olduğu fikri üzerine birleşmişlerdir. Bu dönem çocuğun kişiliğinin şekillenmesinde kritik bir dönemdir. Özellikle çocuğun yeteneklerinin ortaya çıkarılması, ihtiyaçlarının karşılanması, yaşama uyum için temel alışkanlıkların kazandırılması ve onu ilköğretime hazırlaması nitelikli bir okul öncesi eğitimle gerçekleşebilir. Okul öncesi eğitimi vermekle yükümlü olan kurumlar, çocukların bireysel farklılıklarına ve gelişim özelliklerine uygun çok sayıda uyarıcının bulunduğu ortamı sunan ve onların tüm gelişimlerini toplumun kültürel değerleri ve özellikleri doğrultusunda en iyi biçimde yönlendiren, çocukları toplumsal yaşama, geleceğe ve temel eğitime hazırlamada aileye destekle sorumludur (Zembat, 2005).

Çocuklar; soru soran, yaratıcı güçlerini kullanarak hayal eden, sürekli öğrenme durumu ile ilgili merakını giderme ihtiyacı taşıyan bireylerdir. Çocukların bu meraklarının doğru bir şekilde giderilmesi planlanmış, sistemli bir eğitim sayesinde olmaktadır. Çocukların bu ihtiyaçlarının karşılanmasında ise okul öncesi eğitim büyük rol oynamaktadır.

Okul öncesi dönem çocuğun doğumundan itibaren ilkokul çağına kadar geçen yaklaşık 6 yıllık bir süreci kapsamaktadır. Okul öncesi eğitimle ilgili çeşitli tanımlar yapılmakla birlikte hepsinin temelde birbirine benzediği görülmektedir. Okul öncesi eğitim; zorunlu eğitim çağ 1 başlayana kadar çocukların, beden, zihin, duygu ve sosyal gelişimlerini düzenli bir ortam içinde daha iyi gerçekleştiren, onlara iyi alışkanlık ve davranışlar kazandıran, var olan yeteneklerinin geliştirilmesine katkı sunan, onları ilköğretime hazırlayan bir eğitim sürecidir (Taner ve Başal, 2005).

Çocukların okul öncesi yılları, öğrenme potansiyellerinin oldukça yüksek olduğu ve kişilik temellerinin atıldığı dönemdir. Çocukların bu dönemde karşılaş̧ış olduğu tüm yaşantılar, en az kalıtımsal özellikleri kadar önemlidir. Bu döneme denk gelen okul öncesi yaşları; ileri yaşlara olan etkisi nedeniyle, yaşamın kritik dönemlerinden biri olarak görülmektedir. Bu dönemde çocuğa sağlanacak deneyimlerle kazanacağı bilgi, beceri ve alışkanlıklar, onun sonraki öğrenim yaşamının yanı sıra sosyal ve duygusal yaşamını da biçimlendirecek güçtedir. Dolayısıyla okul öncesi dönemde çocukların aldığı eğitim daha sonraki yaşantılarında önemli bir etken haline gelmiştir (Argon ve Akkaya, 2008).

Okulöncesi eğitimin en önemli unsurlarından biri öğretmenlerdir. Bu dönemde, çocuk ilk kez aileden ayrılacağı için öğretmen, çocuğun okula uyum sağlamasında önemli rol oynar Okul öncesi eğitim sürecinde, öğrencilerin gelişim alanları öğretmenleri tarafından desteklenmektedir. Aynı zamanda onların istenmedik davranışlarının önlenmesi, istendik davranışlar kazanmaları, ileride özdenetimlerini sağlayan bireyler olması için öğretmenlere çok önemli görevler düşmektedir (Akman, Akyol, Arslan, Baydemir ve Kükürtçü, 2011). Bu görevlerin etkili bir şekilde yerine getirilmesi ise kaliteli ögretmenlerle mümkündür. Okutan (2003)'a göre, okul öncesi eğitim yaşantılarının, kaliteli mekânlarda, çocukların gelişimlerine, ilgi ve ihtiyaçlarına cevap verebilen etkili programlarla sağlanması nitelikli öğretmenlerle mümkündür. Bundan dolayı nitelikli okul öncesi öğretmenlerinin sayılarının arttırılması; çalışma koşullarının düzenlenmesine ve sorunlarının ortaya koyulup etkili bir şekilde çözülmesine bağlıdır.

\subsection{Araştırmanın Amacı}

Bu çalışma; Mersin ili Toroslar ilçesinde devlet okul öncesi eğitim kurumlarında çalışan okul öncesi öğretmenlerinin okul öncesi eğitimde var olan sorunların erkek okul öncesi öğretmenlerince ne düzeyde yaşandığına ilişkin görüşlerini tespit etmek amacıyla yapılmıştır. Bunun yanında okul öncesi eğitimdeki sorunların erkek okul öncesi eğitim öğretmenlerinde ne düzeyde yaşandığını bazı değişkenler (cinsiyet, kıdem, yaş, medeni durum, mezuniyet, okuttuğu şube, çalıştığı okul türü) açısından incelemek araştırmanın bir diğer amacı olarak belirtilebilir. 


\subsection{Problem Durumu}

Hızla gelişen ve değişen günümüz dünyasında insanların yaşam ve düşünme biçimleri, değer yargıları, beklenti ve sorunları da değişmiş, küreselleşmenin de etkisiyle insanların birbirini daha fazla etkilediği bir sürece girilmiştir. Eğitim ve öğretimin merkezinde insanın olduğu düşünüldüğünde yaşanan bu gelişmelerden en çok etkilenen meslek gruplarından birinin de öğretmenlik mesleği olduğu tespiti ve çözüm arayışları ihmal edilmemesi gereken çok önemli bir olgu olmaya devam etmektedir. Özellikle ögretmenin yetişme sürecinden itibaren sorunlar üzerinde durmak uzun vadeli yatırım olan eğitimin başarısına olumlu etki yapacaktır (Demir ve Ar1, 2013)

Öğretmenlerin meslek hayatında başarısını etkileyen en önemli öğelerin başında yaşadıkları problemlerin geldiği tespit edilmiştir. Geçen yıllar hem ülke olarak hem de eğitim ve bilim alanındaki ilerlemeler öğretmen sıkıntılarının nicelik ve niteliksel değişime maruz kalmasına etki etmiş olabilir. Öğretmen problemlerini ilgilendiren en nitelikli çalışmalardan birisi de TÖB-DER tarafından yapılan ve UNESCO Milli Daimî Komisyonuna sunulan raporda bulunmaktadır. Bu rapora göre, öğretmenlerin genel olarak sıkıntıları; geçim sıkıntısı, güvenlik, hukuksal, öğretmen dağılımı ve atamalar ile öğretmenlerin gruplanması olarak belirlenmiş̧tir (Demir ve Arı, 2013).

Ülke genelinde yapılan araştırmalar da okul öncesi öğretmenlerinin mesleklerinde karşılaştıkları problemler üzerine araştırmalar yapılmıştır. Bu araştırma sonuçlarına göre genel olarak; okul öncesi öğretenlerinin okul yönetimi, meslektaşları ve veliler ile bazı sorunlar yaşadıkları görülmektedir.

Bennet ve Kell (1984) okul öncesi eğitimin verildiği çocukların olduğu okullarda yaptıkları araştırmada şu sorunlar ortaya çıkmıştır: Öğretmenlerin geneli; koşulların daha iyi olması yönünde fikir belirtmişlerdir. Bunlardan bazıları mekânsal yetersizlik, materyal açısından eksiklikler, sınıf mevcudunun kalabalık olması gibi birtakım etkenlerden dolayı çocuklarla bireysel ilgilenememe durumundan dolayı sorun yaşadıklarını belirtmişlerdir. Okul müdürleri ise; nitelikli personel eksikliği, mekân yetersizliği, sınıf mevcudunun kalabalık olması gibi güçlüklerle karşılaştıklarını belirtmiştir. Haley (1984) Nova Üniversitesi'nde sunduğu araştırma raporunda öğretmenlerin okul öncesi eğitimde yer verilen etkinliklerde eşit seviyede bilgiye sahip olmadıklarını açıklamıştır. Bunun için ögretmenlere iki ay süreyle hizmet içi eğitimler verilmiştir (akt. Başturan, 2018).

Yapılan araştırmalarda; öğretmenlerin bu sorunlardan okul yönetimi ile yaşadıkları problemlerin genel olarak; yöneticinin özel gün ve haftalarda sunulmak üzere okul öncesi öğretmenlerinden sinıfça hazırlanan etkinlik talep etmesi, anasınıfı aidatlarının kullanımı, sınıfın fiziksel şartlarındaki eksiklikler ve materyal eksikliği, yöneticiler tarafından okul öncesi eğitimin öneminin yeterince kavranamaması, öğretmenin yardımcı personel talebine duyarsız kalınması, yöneticinin öğretmenlere eşit mesafede olmaması gibi durumlar olduğu belirtilmiştir (Zembat, 2012). Okul öncesi eğitimi öğretmenlerinin yaşadıkları sorunlar ile ilgili yapılan bir araştırma raporunda ise; öğretmenlerin büyük çoğunluğunun okul yönetimiyle sorun yaşadığı sonucuna ulaşılmış. Okul yönetimiyle yaşanılan sorunlar ise; okul öncesi eğitim programından yöneticilerin haberdar olmaması, yönetimin istek ve temennilere karşı ilgisiz olması, sınıftaki eksikliklerden kaynaklı sorun yaşanması, iletişim eksikliği gibi nedenler olarak belirtilmiştir (Kaya, 2013).

Zembat'ın (2012) yaptığı araştırmada öğretmenlerin meslektaşlarıyla yaşadıkları problemlerin genel olarak; farklı branş ve eğitim düzeylerinden olan öğretmenlerin bir arada çalışması, bilgi paylaşımında eksiklik, yarım gün eğitim veren kurumlarda iki öğretmenin aynı sınıfı kullanmak durumunda kalması, rekabet, tükenmişlik, ortak hareket edememe, öğretmenler arasında gruplaşma ve okul öncesi öğretmeninin diğer branş öğretmenlerince küçümsenmesi gibi davranışların ön plana çıktığ1 belirtilmiştir. Kaya'nın (2013) yaptığı araştırma raporunda öğretmenlerin meslektaşlarıyla yaşadıkları sorunların genel olarak; aynı sınıfinı kullanılma durumu, ortak bir plan olmadığından rekabet durumunun olmasından kaynaklı kıskançlık durumlarının yaşanması, toplu etkinliklerde ortaya çıkan fikir farklılıkları, kız-erkek sayısı eşitliliği ile sabahçı-öğlenci grupları arasındaki öğrenci sayısı tutarsızlığı gibi durumlar belirtilmiştir.

Yapılan araştırmalarda; okul öncesi öğretmenlerinin genel olarak velilerle de problem yaşadığı görülmektedir. $\mathrm{Bu}$ doğrultuda velinin öğretmenden beklentilerinin en önemli sorun alanlarından biri olduğu tespit edilmiştir. Bu beklentilerin neler olduğu ile ilgili ülkemizde yapılan birçok araştırma 
bulunmaktadır. Okul öncesi öğretmenlerinin de bu beklentilerin bazılarını karșılarken problemler yaşadıkları görülmektedir (Özen, 2008). Kaya’nın (2013) yaptığı araştırma sonucunda öğretmenlerin velileriyle yaşadıkları sorunların genel olarak; velilerin okul öncesi eğitimi bakıcılık olarak algılamaları, bilgisiz olmaları, velilerin kişisel özellikleri, velilerin ilgisiz olmaları, malzeme alımı ve toplantılara katılım konularında yaşanan sıkıntılar, aidat gibi maddi konularda tartışmalar, iyi iletişim kuramamaktan kaynaklanan sorunlar olduğu belirtilmiştir.

Okul öncesi eğitim kurumlarında görev yapan öğretmenler genelde kadındır. Oysa ki, erkek ögretmenlerin, çocuklar için olumlu erkek figürleri olmaları nedeniyle okul öncesi eğitimindeki gereklilikleri konusunda güçlü bir görüş vardır (Gülçiçek, 2017). Dee (2006), erkek öğretmenlerin farklı tarzlarının, seslerinin ve sınıftaki varlıklarının, öğretmene daha iyi cevap vermeleri için çocukları etkilediğini ve erkeklerin özellikle erkek öğretmenler tarafından öğretildiğinde daha yüksek bir başarı sergilediklerini iddia etmiştir. D'Arcy (2004), erkek öğretmenlerin iletişim ve ilişkideki çocuklarla etkileşime girme bakımından kadın meslektaşlarından farklı olduğunu, yani çocukların cinsiyet çeşitliliğini tecrübe etmesi gerektiğini belirtmiştir. Ayrıca, erkek öğretmenler çocuklarına kendi deneyimlerini yaşatmakta ve erkek perspektifli etkinliklere katkıda bulunduğunu, erkek ve kadın öğretmenlerin okul ortamlarındaki iş birliğinin, çocukların karşı cinsiyetle sosyalleşmelerini sağladığını belirtmiştir. Russo ve Feder (2001) ise, erkek öğretmenlerin çocukların her iki cinsiyete de eşit saygı duymayı öğrenmelerini sağladıklarını ve bu durumunda toplumdaki cinsiyet eşitliğini desteklediğini belirtmişlerdir. Elicker (2002), erkek öğretmenlerin okul öncesi eğitimdeki sayıları arttıkça, babaların okul öncesi eğitimde daha aktif olduğunu doğrulamıştır. Bunun nedeninin ise, erkek okul öncesi öğretmenlerinin babaların kendilerini rahat hissetmelerini sağlamaları olduğu ifade edilmiştir (Jones, 2009). Başka bir deyişle, okul öncesi eğitimdeki erkek öğretmenlerin varlığının erkeklerin de çocukların yaşamlarında sorumluluk alabileceğini ima ettiği ve bu öğretmenlerin babaları çocuklarının eğitiminde daha aktif olmaları için teşvik ettiğini göstermektedir (Öztürk, 2012).

Bu bulgulardan, erkek okul öncesi öğretmenlerinin okul öncesi eğitimdeki katkılarının önemli olduğu sonucuna ulaşabiliriz. Bu durumda, öğretmenlerin de bu alanda yaşadığı sorunların ortaya konulmasının önemi ortaya çıkmaktadır. Özellikle; erkek öğretmen görmeye alışkın olmayan öğrenci velileri, okul yönetimi, kadın öğretmenler ve öğrenciler zaman zaman şaşkınlık yaşamaktadırlar. Bu durumun bir yansıması olarak da erkek öğretmenler mesleki görevlerini yerine getirirken çeşitli sorunlarla karşılaşmaktadırlar (Sak, 2005). Bu sorunların neler olduğunun incelenmesi ve belirlenen sorunlara istinaden üretilecek çözüm önerileri erkek okul öncesi öğretmenlerinin mesleki yaşantılarında karşılaşacakları sorunlara karşı nasıl hareket etmesi konusunda bakış açısı sağlamasına yardımcı olacaktır.

\subsection{Problem Cümlesi ve Alt Problemler}

Okul öncesi eğitimde var olan sorunlar erkek okul öncesi öğretmenlerince ne düzeyde yaşanmaktadır?

\section{Alt Problemler}

Mersin ili Toroslar ilçesindeki kamu anaokulu ve anasınıflarında görev yapmakta olan öğretmenlerin okullarında yaşadıkları;

1. Okul öncesi eğitim sorunlarına ilişkin katılım düzeyleri nedir?

2. Okul öncesi eğitimin sorunlarının erkek okul öncesi öğretmenlerince ne düzeyde yaşandığına ilişkin katılım düzeyleri nedir?

3. Cinsiyet, kıdem, yaş, medeni durum, mezuniyet, okuttuğu şube, çalıştığı okul türü değişkenlerine göre; öğretmenlerin okul öncesi eğitimin sorunlarına ilişkin katılım düzeyleri arasında anlamlı fark var midir?

4. Cinsiyet, kıdem, yaş, medeni durum, mezuniyet, okuttuğu şube, çalıştığı okul türü değişkenlerine göre; öğretmenlerin okul öncesi eğitimin sorunlarının erkek okul öncesi öğretmenlerince ne düzeyde yaşandığına ilişkin katılım düzeyleri arasında anlamlı fark var mıdır?

\subsection{Araştırmanın Önemi}

Okul öncesi eğitim; 0-6 yaş grubu çocukların bireysel özelliklerine ve gelişimsel düzeylerine uygun, donanımlı uyarıcı çevre olanakları sağlayan ve çocukların gelişimlerini içinde bulunduğumuz 
toplumun kültürel değerleri doğrultusunda en iyi şekilde yönlendiren eğitim sürecidir (Çetinkaya, 2010). Sağlıklı ve istenilen davranışlara sahip çocuklar yetiştirmek okul öncesi eğitimin en önemli amaçlarından biridir. Bu amaçları gerçekleştirmede en önemli paydaşlardan biri de öğretmenlerdir. (Şimşek ve İvrendi, 2014). Günümüzde okul öncesi dönemde erkek öğretmenler de görev almaya başlamış bulunmaktadır. Geçmiş yıllarda hep kadınlar tarafından yapılan bu meslekte erkek öğretmen görmek alışkın olunmadık bir durumdur.

Okul öncesi öğretmenleri görevlerini yerine getirirken çeşitli sorunlarla karşılaşmaktadırlar. Alan yazın taraması yapıldığında genel olarak okul öncesi eğitimin sorunları ile ilgili araştırmalar bulunmaktadır. Fakat erkek okul öncesi öğretmenlerinin mesleki görevlerini yerine getirirken karşılaştığı sorunlarla ilgili Türkiye'de yapılmış herhangi bir araştırmaya rastlanmamış olup bu yönüyle araştırmanın okul öncesi eğitim alanına katkısının olacağı düşünülmektedir.

$\mathrm{Bu}$ araştırma ile Mersin ili Toroslar ilçesindeki kamu anaokulu ve anasınıflarında görev yapan okul öncesi öğretmenlerinin okul öncesi eğitimin sorunları ve bu sorunların erkek okul öncesi ögretmenlerince ne düzeyde yaşadıklarını tespit etme amaçlanmıştır. Bu doğrultuda bu çalışma ile erkek okul öncesi öğretmenlerin görevlerini yerine getirirken karşılaştı̆̆ sorunların ne düzeyde yaşadıklarını tespit ederek yüksek düzeyde yaşadıkları sorunlara istinaden üretilecek çözüm önerileri ile erkek okul öncesi öğretmenlerinin mesleki yaşantılarında karşılaşacakları sorunlara karşı erkek öğretmenlerin nasıl hareket etmeleri konusunda kendilerine bakış açıları sağlaması açısından önem taşımaktadır.

\section{2. İLGILII ARAȘTIRMALAR}

Okul öncesi eğitim ve sorunlarılla yapılmış başlıca ilgili araştırmalar şöyle sıralanabilir:

Gündoğan'ın (2002) yaptığı araştırmada Denizli ilinde 52 çalışan 253 okul öncesi öğretmenine kendisi tarafından geliştirilen bir anket uygulamıştır. Araştırma sonucunda, öğretmenlerin çalıştıkları kurumlara göre farklı sorunlarla karşılaştıklarını ortaya koymuştur. Anasınıfında çalışan öğretmenlerin çalışma koşulları açısından bağımsız anaokullarında çalışan öğretmenlere göre daha fazla sorunla karşılaştı̆̆ saptanmıştır. Bunun yanında öğretmenlerin eğitim durumu, meslekteki kıdemleri, branşları ve hizmet içi eğitime katılma durumları ile karşılaşılan sorunlar arasında anlamlı bir farklılık ortaya çıkmıştır (Gündoğan,2002).

Başturan'ın (2018) yaptığı araştırmada, İstanbul ili Anadolu yakasında devlet ve özel okul öncesi eğitim kurumlarında görev yapmakta olan, kartopu örnekleme yoluyla seçilmiş 118 okul öncesi öğretmenine kendisi tarafından geliştirilen okul öncesi öğretmenleri için demografik bilgi formu ve yarı yapılandırılmış öğretmen görüşme formu uygulanmıştır. Araştırma sonucunda devlet ve özel okullarda görev yapan okul öncesi öğretmenlerinin öğretmen görüşme formunda bildirdikleri sorunlar arasından 8 temel sorun tanımı ortaya konulmuş; bu sorunlar araştırmacının yaptığı analiz ve görüşmelere göre; çalışma saatleri ve mola yetersizliği, maaş yetersizliği, sınıf mevcutları, değersizlik, velilerle ilgili problemler, okul şartları ve sınıf materyalleri ile ilişkili problemler olarak ortaya çıkmıştır.

Demircan Aydın'ın (2017) yaptığı araştırmada nitel yöntem kullanılmış olup amaçlı örneklem seçilerek İstanbul ili Levent, Şişli, Kağıthane, Bahçelievler, Bahçelievler, Sarıyer ve Yenibosna ilçelerine bağlı 10 bağımsız anaokulunun ve 10 da bünyesinde ana sınıfını bulunan ilkokulun yöneticileri ve öğretmenlerine görüşme formu uygulanmıştır. Araştırma sonucunda görüşme yapılan ögretmenlerin ve yöneticilerin okul öncesi eğitim sürecinde karşılaştıkları yönetimsel sorunların çalıştıkları kurum çerçevesinde değiştiği görülmüştür. Bağımsız anaokulunda çalışan öğretmenler yönetimsel açıdan ilkokullara bağlı anasınıflarında çalışan öğretmenlere kıyasla daha az sorun yaşadıklarını ifade etmişlerdir.

Gülçiçek’in (2017) yaptığı araştırmada nitel yöntem kullanılmış olup amaçlı örneklem seçilerek araştırmanın örneklemini; Ankara'da yaşayan 11'i kadın 2'si erkek toplam 13 veli oluşturmuştur. Bu çalışmanın bulguları ebeveynlerin eğitim-öğretim yılının başında çocuklarının erkek okul öncesi ögretmenine yönelik olumlu ve olumsuz algıları olduğunu ortaya koymuştur. Olumsuz algılar açısından, katılımcılar erkek ögretmenler ile ilgili olarak; çocuk istismarı, kız çocukları ile iletişim 
kuramama, çocukların öz bakımı ile baş edememe gibi konularda endişeleri olduğunu belirtmişlerdir. Ayrıca erkek öğretmenlerin anne olmama durumunu bir dezavantaj olarak görmüşlerdir. Olumlu algılar açısından, katılımcılar erkek öğretmenlerin çocuklar üzerinde daha fazla kontrolü olduğunu ve erkeklerin anne olmama durumunu onlar için bir avantaj olarak görmüşlerdir.

Çetinkaya’nın (2010) yaptığı araştırmada 2009-2010 öğretim yılı ikinci döneminde İstanbul ili Bahçelievler ilçesindeki resmi ilköğretim okullarının anasınıflarında çalışan tesadüfi örnekleme yoluyla seçilen 35 resmi ilköğretim okulunda görev yapmakta olan 135 okul öncesi öğretmenine, araştırma kapsamında geliştirilen anket uygulanmıştır. Okul öncesi eğitimde fiziki yapı, bu araştırmanın esas konusunu oluşturmuştur. Çalışmanın sonunda; anasınıflarının yarısında yemekhane bulunmadığı, olanların ise ihtiyaçları karşılamada yetersiz kaldığı, anasınıflarının yarısında yemek yenilen ortamlarda güvenlik önlemlerinin alınmadığı, sınıf büyüklüğü öğrenci sayısına göre önemli bir kesim tarafından yeterli bulunmuş ancak kurumların bina içindeki ve dıșındaki alanları çocukların serbestçe oynamasına imkan sağlayacak nitelikte ve ferahlıkta olmadığı, sosyal aktivitelerin düzenlenebileceği alanlar olmadığı ve binada veliler ile bireysel görüşmelerin yapılabileceği ayrı bir alan olmadığı, anasınıflarında ihtiyacı karşılar düzeyde ilgi köşesi bulunduğu, bu ilgi köşelerindeki materyallerin çocukların rahatlıkla oynayabilecekleri biçimde güvenli, uygun olduğu ve teknolojik araçların da bulunduğu ancak ilgi köşelerindeki materyallerin sayıca yetersiz olduğu, anasınıflarının pencere ve kapı özelliklerinin çocukların güvenlikli, 1sı ve gürültü yalıtımlı sağlıklı bir ortamda eğitim almalarını sağlama açısından standartlara uygun olduğu, sınıf içi tüm alanların ve sınıftaki eşyaların düzenli olarak temizlendiği, mutfak araç-gereçlerinin sağlık kurallarına uygun olduğu sonuçlarına ulaşı1mıştır.

Ağgül Yalçın ve Yalçın'ın (2018) yaptığı araştırmada tarama yöntemi kullanılarak araştırmanın örneklemi Ağr1 il merkezindeki okullarda görev yapan 82 okul öncesi öğretmeninden oluşmuştur. Araştırmacılar tarafından hazırlanan ve 12 açık uçlu soru içeren yazılı görüş formuyla toplanan veriler betimsel analiz yaklaşımı ile analiz edilmiştir. Çalışma sonucunda öğretmenlerin sınıf büyüklüklerinin öğrenci sayısı ve etkinlikler için uygun olmadığını, okul öncesi eğitim kurumlarında bahçenin muhakkak olması gerektiğini, okul öncesi eğitim verilen sınıfların ilköğretimle aynı çatı altında olmaması gerektiği, ailelerin çoğunlukla okul öncesi eğitimi destekledikleri, etkinliklere ara verilmeden devam edilmesinin çocuklar ve öğretmenler için uygun olmadığını, anne ve baba tutumlarının uygulamaları ve etkinlikleri olumsuz etkilediklerini düşündükleri belirlenmiştir. Ayrıca öğretmenlerin, beslenme konusunda çocukların yemek seçmesi, ailelerin gönderilen listeye uymaması, sağlısız beslenme istekleri gibi hususlarda sorun yaşadıkları, okul öncesi eğitim programının kazanım ve göstergeler açısından anlaşılır olmadığını düşündükleri, programın uygulanabilmesi için sınıf büyüklüklerinin ve materyal eksikliklerinin sorun olduğunu düşündükleri, programın değerler, din eğitimi gibi konularda yetersiz olduğunu ve öz bakım becerilerini kazandırmada yetersizlikler taşıdığını düşündükleri çalışmanın ulaşılan sonuçları olmuştur.

Kök, Küçükoğlu, Tuğluk ve Koçyiğit’in (2007) yaptıkları araştırmada betimsel araştırma yöntemi kullanılmış ve öğretmen görüşleri taranmıştır. Araştırma evrenini Erzurum ilinde görev yapan 80 okul öncesi öğretmeni oluşturmuştur. Araştırmada örneklem tespitine gidilmemiş ve Büyükşehir belediye sınırlarındaki tüm okul öncesi öğretmeni araştırmaya dahil edilmiştir. Araştırma sonuçlarına göre; Öğretmenlerin neredeyse tamamı sınıflarının okul öncesi eğitiminin gereklerine ve öğrenci ihtiyaçlarına uygun olmadığını, sınıfların fiziki donanımının yetersiz olduğunu, araç gereç ve materyallerinin eski ve yetersiz olduğunu ve okulun çevre düzenlemesi ve oyun bahçesinin olmadığını veya yetersiz olduğunu ifade etmiştir. Öğretmenler okul içi genel planlama sınıf içi faaliyetleri planlamada okul idaresinin engelleriyle karşılaştıklarını, program içeriğinin yeterli olmadığını ve üzerinde değişiklik yapılmasına izin verilmediğini, ayrıca yeni plan yapma konusunda kendilerinin yeterince bilgili olmadıkları gibi bu konuda onlara rehberlik edecek kişilerinde olmadığını ifade etmişlerdir.

Sak'ın (2005) yaptığı araştırmada örneklem bölgeler arası gelişmişlik düzeyleri dikkate alınarak rastgele örnekleme yöntemiyle seçilmiştir. İç Anadolu Bölgesinden 46, Doğu Anadolu bölgesinden 60 olmak üzere, iki bölgeden toplam 106 erkek okul öncesi öğretmeni ile her iki bölgedeki erkek öğretmen sayıları göz önünde bulundurularak İç Anadolu Bölgesinden 132, Doğu Anadolu 
Bölgesinden 143 olmak üzere toplam 275 öğrenci velisi araştırma kapsamına alınmıștır. Araștırmada araştırmacı tarafindan geliştirilen anket kullanılmıştır. Araştırma sonucunda; İlçe ve daha küçük yerleşim yerlerinde göreve başlayan erkek öğretmenlerin şehir merkezinde göreve başlayan erkek ögretmenlerden daha fazla olumsuz durumlarla karşılaştıkları bulunmuştur. 3 yıl ve üzeri kıdeme sahip erkek okul öncesi öğretmenlerin göreve başladıklarında 2 y1l ve daha az kıdeme sahip erkek öğretmenlerden daha fazla olumsuz durumlarla karşılaştıkları saptanmıştır. 27-32 yaş aralığındaki erkek okul öncesi öğretmenlerin göreve başladıklarında 22-26 yaş aralığındaki erkek öğretmenlerden daha fazla olumsuz durumlarla karşılaştıkları saptanmıştır. İç Anadolu Bölgesindeki velilerin erkek öğretmen ile ilk karşılaştıklarında Doğu Anadolu Bölgesindeki velilerden daha fazla olumsuz yargılara sahip oldukları ancak bu olumsuz yargılarından daha sonra kurtulduklar1 ve bunların yerine olumlu yargılar geliştirdikleri bulunmuştur. Erkek çocuğa sahip velilerin, erkek öğretmenler hakkında kız çocuğa sahip velilerden daha fazla olumlu yargılara sahip oldukları saptanmıştır. İç Anadolu Bölgesindeki velilerin yaşlarına göre maddelere verdikleri yanıtlar karşılaş̧ırıldığında hiçbir maddede anlamlı fark olmadığı ancak Doğu Anadolu Bölgesindeki 31 yaş ve üstü velilerin, erkek öğretmenler hakkında 30 yaş ve altı velilerden daha fazla olumlu yargılar geliştirdikleri bulunmuştur. Velilerin eğitim düzeyleri arttıkça erkek okul öncesi öğretmenleri hakkındaki olumsuz yargılarının azaldığı saptanmıştır.

Zaimoğlu Öztürk, Kaya ve Durmaz’ın (2015) yaptığı araştırma tarama modelinde yapılmış olup veriler nitel araştırma yöntemi kullanılarak toplanmıştır. Araştırmanın çalışma grubunu 2012-2013 eğitim-öğretim y1lında MEB tarafından okul öncesi öğretmenlerine yönelik olarak düzenlenmiş bir hizmet içi eğitim faaliyetindeki 208 öğretmen oluşturmuştur. Araştırma sonuçlarına göre, katılımcıların karşılaştığı sorunlar arasında, öğretmenlerin \%55,8'inin okul yönetimi ile sorun yaşamadıkları, \%38,5'inin ise sorun yaşadıklarını belirttikleri, öğretmenlerin okul yönetimi ile yaşadıkları en önemli sorunlar arasında, okul yönetiminin okul öncesi eğitim programından yeterince haberdar olmamaları $(\% 26.6)$ ve yönetimin istek/temennilere ilgisiz olmaları $(\% 19,1)$ ve katılımcıların zümre arkadaşlarıyla yaşadıkları en sık sorun "Aynı sınıfın kullanılması $(\% 25,5)$ ”, ikinci sık sorun da "Ortak bir plan olmadığından rekabet ortamı olması, kıskançlık $(\% 21,6)$ " gibi sorunlar yaşadıkları tespit edilmiştir.

Ergen ve Günay'ın (2019) yapmış oldukların araştırmada; Mersin ili Erdemli ilçesinde çalışan ögretmenlerin yaşadığı yönetimle ilgili sorunlar hakkındaki görüşleri anket yoluyla elde edilmiştir. Araştırma bulgularına göre; öğretmenlerin genelde "şikayetçi” olmadıkları ancak sorunların çözümüne daha fazla katılmak istedikleri ortaya çıkmıştır. Bu durum; öğretmenlerin üst düzey ihtiyaçlarına yönelik motivasyon faktörlerinin sağlanmasını bekledikleri şeklinde yorumlanmıştır.

\section{YÖNTEM}

Bu bölümde yapılan çalışmada, çalışmanın evreni, örneklemi, veri toplama aracı, veri toplama aracının nasıl uygulandığı, toplanan verilerin değerlendirilmesi sırasında kullanılan istatistiki yöntemlere yer verilmiştir.

\subsection{Araştırmanın Modeli}

$\mathrm{Bu}$ araştırmada okul öncesi eğitim kurumlarında çalışan erkek okul öncesi eğitimi öğretmenlerinin karşılaştı̆̆ sorunları inceleme amacıyla tarama modellerinden biri olan betimsel tarama modeli uygulanmıştır. Betimsel tarama, geniş gruplar üzerinde yürütülen, gruptaki bireylerin bir olgu ve olayla ilgili görüşlerinin, tutumlarının alındığı, olgu ve olayların betimlenmeye çalışıldığı araştırmalardır (Karakaya, 2012, s. 59).

\section{2. Çalışma Grubu}

$\mathrm{Bu}$ araştırma, Mersin ili Toroslar ilçesinde devlet okul öncesi eğitim kurumlarında çalışan okul öncesi öğretmenlerinin okul öncesi eğitimde var olan sorunların erkek okul öncesi öğretmenlerince ne düzeyde yaşandığını tespit etmek amacıyla yapılmıştır. Çalışmada veri toplanan okullar bağımsız (Kamu) anaokulları ile kamuya ait anasınıflarıdır.

Çalışma Mersin ilinin Toroslar ilçesinde yürütülmüştür. Toroslar nüfusu 2018 y1lı sonu itibari ile 295.663'dür. Toroslar İlçesi, nüfus bakımından genel olarak Mersin'in yerli halkının yer aldığı bir 
ilçedir. Bölgede büyük sanayi kuruluşlarının azlığı insanları eğitim ve öğretimi önemsemeye ve devlet memurluğunu tercih etmelerine yol açmıştır. Okula ve eğitime değer veren, kadınlarının da çoğunun çalıştığı bir bölgede okulöncesine ihtiyaç ve katılımı arttırmaktadır.

Toroslar ilçesinde; 161 okulda, 1965 derslikte, 68.803 öğrenciye 3366 öğretmen ile eğitim verilmektedir. Derslik başına düşen öğrenci sayısı ilk/ortaokulda 39, genel ortaöğretimde 26, mesleki teknik eğitimde ise 26 'dır. İlçede devlete bağlı toplamda 49 okul öncesi eğitim kurumu bulunmaktadır. 10 anaokulu, 39 ilköğretim okulları bünyesinde anasınıfı bulunmaktadır. Devlete bağlı okul öncesi eğitim kurumlarındaki öğrenci sayısı 7222 'dir. Bu branşta 263 kadrolu öğretmen hizmet vermektedir. Öğretmenlerden 241'i kadın, 22'si erkek öğretmendir.

Araştırmanın evrenini Mersin ili Toroslar ilçesinde devlete bağlı okul öncesi eğitim kurumlarında görev yapmakta olan 263 okul öncesi eğitim öğretmenleri oluşturmuştur. Örneklemi; bu evrende ulaş1labilen tüm bireyler oluşturmuş olup evrenin \%90'ına ulaşılmıştır. Araştırma, Toroslar'da kamuya bağlı anasınıfi ve bağımsız anaokullarında çalışan 236 öğretmenle yapılmıştır. Cinsiyet, ögretmenlikteki kıdem yılı, yaş, medeni durum, mezuniyet, yaş grubu ve okul türü değişkenlerine göre öğretmenlerin sayıları hakkındaki detaylı bilgi Tablo 3.1'de verilmiştir.

Tablo 3.1. Araştırmaya katılan öğretmenlerin demografik dağılım istatistiği $(n=236)$

\begin{tabular}{llcccc}
\hline Özellikler & Kategori & $\mathrm{n}$ & $\overline{\mathbf{X}}$ & $\mathrm{ss}$ & $\%$ \\
\hline Cinsiyet & Kadın & 214 & 1,09 & 0,29 & 90,6 \\
Kıdem Yı1ı & Erkek & 22 & & & 9,4 \\
& $0-10$ & 124 & 2,61 & 0,71 & 52,5 \\
& $11-15$ & 80 & & & 33,9 \\
Yaş & $16+$ & 32 & & & 13,6 \\
& $20-30$ & 37 & 2,00 & 0,56 & 15,7 \\
\multirow{3}{*}{ Medeni Durum } & $31-40$ & 160 & & & 67,8 \\
& $41+$ & 39 & & & 16,5 \\
Mezuniyet Durumu & Evli & 183 & 1,22 & 0,41 & 77,5 \\
& Bekâr & 53 & & & 22,5 \\
Yaş Grubu (Şube) & Okul Öncesi Eğitim & 228 & 1,03 & 0,18 & 96,6 \\
& Diğer Eğitim Fak. & 8 & & & 3,4 \\
& 4 yaş & 37 & 3,02 & 0,57 & 15,7 \\
Okul Türü & 5 yaş & 159 & & & 67,4 \\
& $4-5$ yaş & 40 & 1,50 & 0,50 & 16,9 \\
& Anaokulu & 116 & & & 49,2 \\
& Anasınıfi & 120 & & & 50,8 \\
\hline
\end{tabular}

\subsection{Verilerin Toplanması}

Araştırmada veri toplama aracı olarak bir anket formu geliştirilirken bağımsız anaokullarında ve anasınıflarında çalışan okul öncesi öğretmenleri ile okul öncesi eğitimin sorunları hakkında tartışılmış yine bu sorunların ne kadarının erkek öğretmenler tarafından daha fazla sorun olarak görüldüğü üzerine öğretmenler ile konuşularak ön anket maddeleri oluşturulmuştur. Literatür taraması ve öğretmen görüşmelerine dayalı olarak oluşturulan taslak üzerinde beş öğretim üyesinin de görüş ve onayı alınmış ve gerekli düzeltmeler yapılmıştır. Daha sonra 10 öğretmene geliştirilen anket formu uygulanarak anlaşılmayan hususlar düzeltilmiştir. Sonuç olarak, 5'li Likert tipi ölçek puanlaması ile yanıt alınacak şekilde oluşturulan 34 madde, okul öncesi eğitimde yaşanan sorun olduğuna ve erkek öğretmenlerin daha fazla sorun yaşadığına katılma açısından 'Okulöncesi Eğitimde Yaşanan Sorunlar' başlıklı bir anket formu haline getirilmiştir.

Anket formları uygulanmadan önce üniversiteden ve Mersin il Milli Eğitim Müdürlüğünden gerekli izinler alınarak 2018-2019 Eğitim-Öğretim Yılının mart ayı içerisinde Toroslar ilçesinde bulunan okulöncesi öğretmenlerine elden, birebir görüşülerek teslim edilmiştir. Mart ayı içinde 20 günlük süre içerisinde 236 ögretmene uygulanıp hepsinden de eksiksiz bir şekilde gerekli süre içerisinde toplanmıştır. 


\subsection{Verilerin Analizi}

Anket maddelerinden elde edilen puanlar şu kriterlere göre yorumlanmıştır: (a) 1-1,49 arası "hiç katılmıyorum"; (b) 1,5-2,49 aras1 "az kat1lıyorum"; (c) 2,5-3,49 aras1 "orta düzeyde kat1lyorum"; (d) 3,5-4,49 aras1 "çoğunlukla katılıyorum"; (e) 4,5-5,0 arası "tamamen katılıyorum".

Araştırmanın, hedefleri doğrultusunda hazırlanan ölçek tipinde anket formuyla toplanan veriler üzerinde istatistiki çözümlemelerin yapılabilmesi ve verilerin analizi için SPSS programı kullanılmış, verilerin analizinde frekans, yüzde, t-testi, Mann Whitney U testi, tek yönlü varyans analizi (ANOVA testi) alt başlıklarında kullanılan Tukey ve Scheffe teknikleri kullanılmıştır. Analiz yapılırken okul öncesi öğretmenlerinin yaşadığı sorunlar ve erkek okul öncesi öğretmenlerinin yaşadığı sorunlar olarak iki ayrı kısımda inceleme yapılmıştır. Katılımcıların görüşleri arasında anlamlı farklılık olup olmadığ $\mathrm{p}<0,05$ seviyesinde test edilmiştir.

İki kategorili olan medeni durum ve okul türü değişkenlerine ilişkin farkların analizinde t-testi kullanılmıştır. Kıdem yılı, şube ve yaş değişkenlerine ilişkin farklar ise ANOVA ile analiz edilmiş olup, farkların hangi gruplardan kaynaklandığının belirlenmesinde Tukey HSD ve Scheffe analizi yapılmıştır. Cinsiyet ve mezuniyet durumu değişkenlerine ilişkin farklar ise t-testinin parametrik olmayan karşıllı̆̆ olan Mann Whitney U testi ile analiz edilmiştir.

\section{BULGULAR}

Bu bölümde araştırmaya katılan öğretmenlerin her bir maddeye verdikleri yanıtlardan elde edilen puanlar ve bu puanların öğretmen karakteristiklerine göre farklılık oluşturup oluşturmadığına ilişkin test sonuçları yer almaktadır. Öğretmenlerin anket maddelerinde verdikleri yanıtların ortalamaları ve standart sapmaları Tablo 4.1'de görülmektedir.

Tablo 4.1. Anket maddelerinden alınan puanların ortalama ve standart sapmaları

\begin{tabular}{|c|c|c|c|c|c|c|c|}
\hline & \multirow[b]{2}{*}{ Maddeler } & \multicolumn{3}{|c|}{$\begin{array}{c}\text { Okul öncesi } \\
\text { eğitimde sorun } \\
\text { olduğuna katılma }\end{array}$} & \multicolumn{3}{|c|}{$\begin{array}{l}\text { Erkek okul öncesi } \\
\text { öğretmeninin daha } \\
\text { fazla sorun } \\
\text { yaşadığına katılma }\end{array}$} \\
\hline & & $\mathrm{n}$ & $\overline{\mathbf{X}}$ & SS & $\mathrm{n}$ & $\overline{\mathbf{X}}$ & SS \\
\hline 1 & $\begin{array}{l}\text { Okulumuzdaki kişisel ihtiyaçlara yönelik fiziksel koşulların } \\
\text { (lavabo vb.) yeterli olmaması }\end{array}$ & 236 & 2,61 & 1,56 & 236 & 2,55 & 1,58 \\
\hline 2 & $\begin{array}{l}\text { Sınıf, yemekhane ve ortak kullanım alanlarının fiziksel } \\
\text { koşullarının yeterli olmaması }\end{array}$ & 236 & 2,91 & 1,50 & 236 & 2,63 & 1,50 \\
\hline 3 & $\begin{array}{l}\text { Ortak kullanılan sınıf ve alanların temizliğinin öğretmenlerce } \\
\text { yapılması }\end{array}$ & 236 & 2,19 & 1,48 & 236 & 2,28 & 1,59 \\
\hline 4 & $\begin{array}{l}\text { Öğretmenlerin teneffüs ihtiyacını gidermesi için bir düzenleme } \\
\text { olmaması }\end{array}$ & 236 & 4,30 & 1,32 & 236 & 3,77 & 1,69 \\
\hline 5 & $\begin{array}{l}\text { Okul yöneticilerinin okul öncesi eğitimle ilgili bilgisinin yeterli } \\
\text { olmaması }\end{array}$ & $i_{236}$ & 2,54 & 1,47 & 236 & 2,37 & 1,41 \\
\hline 6 & $\begin{array}{l}\text { Okul yöneticilerinin okul öncesi eğitimi öğretmenlerine } \\
\text { olumsuz önyargıyla yaklaşması }\end{array}$ & 236 & 2,33 & 1,45 & 236 & 2,42 & 1,53 \\
\hline 7 & $\begin{array}{l}\text { Denetim ve değerlendirmenin nitelikten çok niceliğe } \\
\text { dayanması }\end{array}$ & 236 & 3,21 & 1,38 & 236 & 2,90 & 1,45 \\
\hline 8 & Öğretmenlere öğrencilerden okul adına para toplatılması & 236 & 3,35 & 1,66 & 236 & 2,93 & 1,74 \\
\hline 9 & Öğretmenlerin evrak yükünün fazla olması & 236 & 3,94 & 1,26 & 236 & 3,36 & 1,55 \\
\hline 10 & $\begin{array}{l}\text { Yöneticilerin okul öncesi eğitimin amaçları dışında } \\
\text { beklentilerinin olması }\end{array}$ & 236 & 2,71 & 1,43 & 236 & 2,59 & 1,47 \\
\hline 11 & Öğretmenlere yardımcı olacak personel yetersizliği & 236 & 3,94 & 1,39 & 236 & 3,73 & 1,48 \\
\hline 12 & $\begin{array}{l}\text { Meslektaşların karşı cinsten öğretmenlere olumsuz önyargıyla } \\
\text { yaklaşması }\end{array}$ & 236 & 2,16 & 1,36 & 236 & 2,62 & 1,59 \\
\hline 13 & $\begin{array}{l}\text { Meslektaşların kendi cinsinden öğretmenlere olumsuz } \\
\text { önyargıla yaklaşması }\end{array}$ & 236 & 2,22 & 1,39 & 236 & 2,23 & 1,42 \\
\hline 14 & Meslektaşların karşı cinsten öğretmenlere mobbing uygulaması & 1236 & 2,05 & 1,36 & 236 & 2,22 & 1,43 \\
\hline
\end{tabular}


15 Sinıflardaki öğrenci sayılarının fazlalığı

17

\section{8}

\section{1}

0 Devam zorunluğu olmaması nedeniyle velilerin esnek davranması

21 Öğrencilerin okula uyumunda sıkıntı yaşanması

22 Sınıftaki öğrencilerin hazır bulunuşluk düzeylerinin farklı olmas1

23 Öğrencilerin öz bakım becerilerinin yeterince gelişmemiş olmas1

24 Okullara görüşmeye genellikle kadın velilerin gelmesi

25 Velilerin çocukların eğitimiyle yeterince ilgilenmemeleri

26 Velileri öğretmenler arasında kıyaslama yapmaları

27 Velilerin okul öncesi eğitimi bakım hizmeti olarak görmeleri

9 olmamas1

30 Eğitim öğretim materyalinin yetersizliği

31 Eğitim programının ihtiyacı karşılamaması

32 Kullanılan öğretim yöntemlerinin amaçlara uygun olmayışı

33 Eğitim programının öğretmenlerce farklı uygulanması

34 Öğretmenlerin özel eğitime gereksinimi olan öğrencilerle ilgili bilgisinin yetersizliği

\begin{tabular}{rrrrrr}
236 & 3,78 & 1,40 & 236 & 3,27 & 1,59 \\
236 & 4,03 & 1,37 & 236 & 3,54 & 1,60 \\
236 & 1,86 & 1,17 & 236 & 2,58 & 1,41 \\
236 & 1,76 & 1,13 & 236 & 2,58 & 1,43 \\
236 & 3,20 & 1,37 & 236 & 2,92 & 1,44 \\
236 & 3,44 & 1,39 & 236 & 3,08 & 1,49 \\
236 & 2,69 & 1,19 & 236 & 2,83 & 1,28 \\
236 & 3,81 & 1,13 & 236 & 3,38 & 1,44 \\
236 & 3,50 & 1,21 & 236 & 3,24 & 1,38 \\
236 & 3,61 & 1,43 & 236 & 3,98 & 1,28 \\
236 & 3,60 & 1,17 & 236 & 3,32 & 1,42 \\
236 & 4,01 & 1,22 & 236 & 4,04 & 1,29 \\
236 & 4,29 & 1,02 & 236 & 4,15 & 1,26 \\
\hline 236 & 4,02 & 1,26 & 236 & 4,20 & 1,27 \\
236 & & & \\
236 & 4,07 & 1,08 & 236 & 3,72 & 1,40 \\
236 & 3,64 & 1,28 & 236 & 3,19 & 1,47 \\
236 & 2,96 & 1,38 & 236 & 2,61 & 1,37 \\
236 & 2,66 & 1,32 & 236 & 2,36 & 1,27 \\
\hline 236 & 1,29 & 236 & 2,84 & 1,31 \\
\hline 236 & 1,29 & 236 & 3,19 & 1,46
\end{tabular}

Araştırma grubunu oluşturan öğretmen adaylarının ankette yer alan ifadelere katılma düzeylerini gösteren sonuçlar Tablo 2'de gösterilmektedir. Her bir ifadenin aldığı ortalamaya göre okul öncesi eğitimde sorun olduğuna katılma durumunda en yüksek oranda katılım; 4, 16, 26, 27, 28, 29. maddelerde iken en düşük oranda katılım ise; 14, 17 ve 18. maddeler de gerçekleşmiştir. Her bir ifadenin aldığı ortalamaya göre Erkek okul öncesi öğretmeninin daha fazla sorun yaşadığına katılma durumunda en yüksek oranda katılım; 26, 27, 28. maddelerde iken en düşük oranda katılım ise; 3, 13, 14 ve 32. maddelerde gerçekleşmiştir.

Okul öncesi eğitimde sorun olduğuna katılma durumu ortalamalarına bakıldığında; "Öğretmenlerin teneffüs ihtiyacını gidermesi için bir düzenleme olmaması" maddesi ankete katılan öğretmenlerin en yüksek sorun olarak gördükleri maddedir (M4, $\overline{\mathbf{X}}=4,30$ ). "İkili öğretimde öğrencilerin sabah ve öğleye dengesiz dağılımı" maddesi öğretmenlerin sorun olarak gördüğü maddelerden biridir (M16, $\overline{\mathbf{X}}$ =4,03). "Velileri öğretmenler arasında kıyaslama yapmaları" maddesi yine öğretmenlerin yüksek düzeyde sorun olarak gördükleri maddelerden biridir (M26, $\overline{\mathbf{X}}=4,01$ ). "Velilerin okul öncesi eğitimi bakım hizmeti olarak görmeleri" maddesi de öğretmenlerin yüksek düzeyde katılımla gördükleri sorunlardandır (M27, $\overline{\mathbf{X}}=4,29)$ ) "Velilerin okul öncesi öğretmenliğini kadın işi olarak görmeleri" maddesi de öğretmenler tarafından sorun olarak görülmüştür (M28, $\overline{\mathbf{X}}=4,02)$. "Velilerin okul öncesi eğitim hakkında yeterli bilgilerinin olmaması" maddesi ankete katılan öğretmenler tarafından yüksek düzeyde sorun olarak görülmektedir (M29, $\overline{\mathbf{X}}=4,07$ ). En düşük oranda sorun gördükleri maddeler ise; "Meslektaşların karşı cinsten öğretmenlere mobbing uygulaması" maddesi (M14, $\overline{\mathbf{X}}=2,05$ ), "Öğrencilerin öğretmeni kabullenmesinde güçlük yaşanması" maddesi (M17, $\overline{\mathbf{X}}=1,86)$, "Öğretmenin öğrencilerin kendilerinden korktuğunu hissetmesi" maddesidir (M18, $\overline{\mathbf{X}}=1,76$ ). Erkek okul öncesi öğretmeninin daha fazla sorun yaşadığına katılma durumu ortalamalarına bakıldığında "Velileri öğretmenler arasında kıyaslama yapmaları" maddesi (M26, $\overline{\mathbf{X}}=4,04)$ ), "Velilerin okul öncesi eğitimi bakım hizmeti olarak görmeleri" maddesi (M27, $\overline{\mathbf{X}}=4,15)$ öğretmenler tarafından erkek öğretmenlerin daha fazla sorun yaşadıklarını düşündükleri maddelerdir. En yüksek oranda erkek öğretmenler için 
daha fazla sorun olarak düşündükleri madde ise; "Velilerin okul öncesi öğretmenliğini kadın işi olarak görmeleri” maddesi (M28, $\overline{\mathbf{X}}=4,20$ ) olarak görülmüştür. En düşük oranda erkek öğretmenlerin sorun yaşadıklarını düşündükleri maddeler ise; "Ortak kullanılan sınıf ve alanların temizliğinin öğretmenlerce yapılması" maddesi (M3, $\overline{\mathbf{X}}=2,28)$, "Meslektaşların kendi cinsinden öğretmenlere olumsuz önyargıyla yaklaşması" maddesi (M13, $\overline{\mathbf{X}}=2,23)$, "Meslektaşların karşı cinsten öğretmenlere mobbing uygulaması" maddesi (M14, $\overline{\mathbf{X}}=2,22)$ ve "Kullanılan öğretim yöntemlerinin amaçlara uygun olmayışı" maddesidir (M32, $\overline{\mathbf{x}}=2,36$ ).

\subsection{Cinsiyet Değişkenine Göre Elde Edilen Bulgular}

Anket maddelerinden elde edilen puan ortalamalarının cinsiyet değişkenine göre farklılık gösterip göstermediğine ilişkin yapılan Mann-Whitney U Testi sonuçları Tablo 4.2'de sunulmaktadır.

Tablo 4.2. Cinsiyet Değişkenine Göre Alınan Mann-Whitney U Testi Sonuçları

\begin{tabular}{|c|c|c|c|c|c|c|}
\hline & & $\mathrm{n}$ & $\overline{\mathbf{X}}$ & SS & $\mathrm{Z}$ & p \\
\hline \multicolumn{7}{|c|}{ Okul öncesi eğitimde sorun olduğuna katılma } \\
\hline \multirow{2}{*}{ M17 } & Kadın & 214 & 114,96 & 1,15 & $-2,735$ & 0,006 \\
\hline & Erkek & 22 & 152,93 & 1,29 & & \\
\hline \multirow{2}{*}{ M24 } & Kadın & 214 & 122,10 & 1,40 & $-2,630$ & 0,009 \\
\hline & Erkek & 22 & 83,45 & 1,53 & & \\
\hline \multicolumn{7}{|c|}{ Erkek okul öncesi öğretmeninin daha fazla sorun yaşadığına katılma } \\
\hline \multirow{2}{*}{ M24 } & Kadın & 214 & 122,22 & 1,20 & $-2,808$ & 0,005 \\
\hline & Erkek & 22 & 82,27 & 1,67 & & \\
\hline \multirow{2}{*}{ M25 } & Kadın & 214 & 121,56 & 1,40 & $-2,200$ & 0,028 \\
\hline & Erkek & 22 & 88,75 & 1,42 & & \\
\hline \multirow{2}{*}{ M30 } & Kadın & 214 & 121,31 & 1,47 & $-2,019$ & 0,043 \\
\hline & Erkek & 22 & 91,18 & 1,40 & & \\
\hline
\end{tabular}

$\mathrm{p}<0,05$

\section{Okul öncesi öğretmeni için sorun:}

“Öğrencilerin öğretmeni kabullenmesinde güçlük yaşanması" maddesinde (M17) öğretmenlerin cinsiyet durumuna göre anlamlı bir farkl1lık bulunmuş olup ( $p=0,006<0,05)$; erkek öğretmenlerin kadın öğretmenlere göre bu maddeyi daha çok sorun olarak gördükleri ortaya çıkmıştır. [ $\overline{\mathbf{X}}=$ Erkek $(152,93)>\operatorname{Kad} ı n(114,96)]$.

"Okullara görüşmeye genellikle kadın velilerin gelmesi” maddesinde (M24) öğretmenlerin cinsiyet durumuna göre anlamlı bir farklılık bulunmuş olup $(\mathrm{p}=0,009<0,05)$; kadın öğretmenlerin erkek öğretmenlere göre bu maddeyi daha çok sorun olarak gördükleri ortaya çıkmıştır. [ $\overline{\mathbf{X}}=\operatorname{Kadın}(122,10)$ $>$ Erkek $(83,45)]$.

\section{Erkek okulöncesi öğretmeni için daha çok sorun:}

“Okullara görüşmeye genellikle kadın velilerin gelmesi” maddesinde (24.madde) öğretmenlerin cinsiyet durumuna göre anlamlı bir farklılık bulunmuş olup $(\mathrm{p}=0,005<0,05)$; kadın öğretmenlerin erkek öğretmenlere göre bu maddeyi erkek okul öncesi öğretmenlerin de daha çok sorun olarak gördükleri ortaya çıkmıştır. [ $\overline{\mathbf{X}}=\operatorname{Kadın}(122,22)>\operatorname{Erkek}(82,27)]$.

"Velilerin çocukların eğitimiyle yeterince ilgilenmemeleri" maddesinde (M25) öğretmenlerin cinsiyet durumuna göre anlamlı bir farklılık bulunmuş olup $(\mathrm{p}=0,043<0,05)$; kadın öğretmenlerin erkek öğretmenlere göre bu maddeyi erkek okul öncesi öğretmenlerin de daha çok sorun olarak gördükleri ortaya çıkmıştır. [ $\overline{\mathbf{X}}=\operatorname{Kadın}(121,56)>\operatorname{Erkek}(88,75)]$.

"Eğitim öğretim materyalinin yetersizliği”" maddesinde (M30) öğretmenlerin cinsiyet durumuna göre anlamlı bir farklılık bulunmuş olup $(\mathrm{p}=0,043<0,05)$; kadın öğretmenlerin erkek öğretmenlere göre bu maddeyi erkek okul öncesi öğretmenlerin de daha çok sorun olarak gördükleri ortaya çıkmıştır. [ $\overline{\mathbf{X}}=$ $\operatorname{Kad} ı n(121,31)>\operatorname{Erkek}(91,18)]$. 


\subsection{Kıdem Değişkenine Göre Elde Edilen Bulgular}

Öğretmenlerin kıdem yılları 0-10 yıl, 11-15 yıl ve 16+ yıl olmak üzere üç kategoride ele alınmıştır. Anket maddelerinden elde edilen puan ortalamalarının kıdem değişkenine göre farlılık gösterip göstermediğine ilişkin yapılan ANOVA sonuçları Tablo 4.3'te sunulmaktadır.

Tablo 4.3. Kıdem Değişkinine Göre Alınan ANOVA Sonuçları

\begin{tabular}{|c|c|c|c|c|c|c|c|}
\hline \multicolumn{3}{|c|}{ Kareler toplamı } & df & Ort. Karesi & $\mathrm{F}$ & $\mathrm{p}$ & Fark \\
\hline \multicolumn{8}{|c|}{ Okul öncesi eğitimde sorun olduğuna katılma } \\
\hline \multirow{3}{*}{ M14 } & Gruplar aras1 & 13,752 & 2 & 6,876 & 3,782 & ,024 & $(11-15)<(16+)$ \\
\hline & Gruplar içi & 423,638 & 233 & 1,818 & & & \\
\hline & Toplam & 437,390 & 235 & & & & \\
\hline \multicolumn{8}{|c|}{ Erkek okul öncesi öğretmeninin daha fazla sorun yaşadığına katılma } \\
\hline \multirow{3}{*}{ M11 } & Gruplar aras1 & 13,803 & 2 & 6,901 & 3,204 & 042 & $(0-10)<(11-15)$ \\
\hline & Gruplar içi & 501,909 & 233 & 2,154 & & & \\
\hline & Toplam & 515,712 & 235 & & & & \\
\hline
\end{tabular}

\section{Okulöncesi öğretmeni için sorun:}

M14: Meslektaşların karşı cinsten öğretmenlere mobbing uygulaması. 11-15 yıl < 16+ yıl. Kıdemi 16 yıl ve üzeri olan öğretmenler ile 11-15 yıl kıdeme sahip öğretmenler arasında "Meslektaşların karşı cinsten öğretmenlere mobbing uygulaması" maddesinde anlamlı bir fark bulunmuş olup, kıdemi 16 yıl ve üzeri olan öğretmenlerin 11-15 yıl kıdeme sahip öğretmenlere göre bu maddeyi daha çok sorun olarak gördükleri ortaya çıkmıştır.

\section{Erkek Okulöncesi Öğretmeni için daha çok sorun:}

M11: Öğretmenlere yardımcı olacak personel yetersizliği. 0-10 yıl < 11-15 yıl. Kıdemi 11-15 yıl olan öğretmenler ile kıdemi 10 yılın altında olan öğretmenler arasında "Öğretmenlere yardımcı olacak personel yetersizliği" maddesinde anlamlı bir fark bulunmuş olup, kıdemi 11-15 yıl olan ögretmenlerin 10 yılın altında kıdeme sahip öğretmenlere göre bu maddeyi erkek okul öncesi öğretmenlerinde daha çok sorun olarak gördükleri ortaya çıkmıştır.

\subsection{Yaş Değişkenine Göre Elde Edilen Bulgular}

Öğretmenlerin yaş durumları 20-30, 31-40, 41+ olmak üzere üç kategoride ele alınmıştır. Anket maddelerinden elde edilen puan ortalamalarının yaş değişkenine göre farlılık gösterip göstermediğine ilişkin yapılan ANOVA sonuçları Tablo 4.4'te sunulmaktadır.

Tablo 4.4. Yaş Değiş̧kinine Göre Alınan ANOVA Sonuçları

\begin{tabular}{|c|c|c|c|c|c|c|c|}
\hline \multicolumn{3}{|c|}{$\begin{array}{l}\text { Kareler toplamı } \\
\end{array}$} & $\mathrm{df}$ & Ort. karesi & $\mathrm{F}$ & $\mathrm{p}$ & Fark \\
\hline \multicolumn{8}{|c|}{ Okul öncesi eğitimde sorun olduğuna katılma } \\
\hline \multirow{3}{*}{ M13 } & Gruplar aras1 & 13,478 & 2 & 6,739 & 3,544 & ,030 & $(20-30)>(31-40)$ \\
\hline & Gruplar içi & 443,064 & 233 & 1,902 & & & \\
\hline & Toplam & 456,542 & 235 & & & & \\
\hline \multirow{3}{*}{ M14 } & Gruplar aras1 & 21,779 & 2 & 10,890 & 6,105 & ,003 & $(20-30)>(31-40)$ \\
\hline & Gruplar içi & 415,611 & 233 & 1,784 & & & \\
\hline & Toplam & 437,390 & 235 & & & & \\
\hline \multirow{3}{*}{ M16 } & Gruplar aras1 & 13,206 & 2 & 6,603 & 3,557 & ,030 & $(20-30)<(31-40)$ \\
\hline & Gruplar içi & 432,523 & 233 & 1,856 & & & \\
\hline & Toplam & 445,729 & 235 & & & & \\
\hline \multicolumn{8}{|c|}{ Erkek okul öncesi öğretmeninin daha fazla sorun yaşadığına katılma } \\
\hline \multirow{3}{*}{ M18 } & Gruplar aras1 & 17,274 & 2 & 8,637 & 4,317 & ,014 & $(31-40)<(41+)$ \\
\hline & Gruplar içi & 466,196 & 233 & 2,001 & & & \\
\hline & Toplam & 483,470 & 235 & & & & \\
\hline
\end{tabular}


$\mathrm{p}<0,05$

\section{Okulöncesi öğretmeni için sorun:}

M13: Meslektaşların kendi cinsinden öğretmenlere olumsuz önyargıyla yaklaşması. 20-30> 31-40. Yaşı 20-30 arasında olan öğretmenler ile yaş1 31-40 arasında olan öğretmenler arasında "Meslektaşların kendi cinsinden öğretmenlere olumsuz önyargıyla yaklaşması" maddesinde anlamlı bir fark bulunmuş olup ( $\mathrm{p}=0,030<0,05)$; yaşı 20-30 arasında olan öğretmenler yaş1 31-40 arasında olan öğretmenlere göre bu maddeyi daha çok sorun olarak gördükleri ortaya çıkmıştır.

M14: Meslektaşların karşı cinsten öğretmenlere mobbing uygulaması. 20-30 > 31-40. Yaşı 20-30 arasında olan öğretmenler ile yaşı 31-40 arasında olan öğretmenler arasında "Meslektaşların karşı cinsten ögrretmenlere mobbing uygulaması" maddesinde anlamlı fark bulunmuş olup $(p=0,003<0,05)$; yaşı 20-30 arasında olan öğretmenler yaşı 31-40 arasında olan öğretmenlere göre bu maddeyi daha çok sorun olarak gördükleri ortaya çıkmıştır.

M16: İkili öğretimde öğrencilerin sabah ve öğleye dengesiz dağılımı. 20-30<31-40. Yaş1 20-30 arasında olan öğretmenler ile yaşı 31-40 arasında olan öğretmenler arasında" İkili öğretimde öğrencilerin sabah ve öğleye dengesiz dağılımı" maddesinde anlamlı bir fark bulunmuş olup $(\mathrm{p}=0,030<0,05)$; yaşı 20-30 arasında olan öğretmenler yaşı 31-40 arasında olan öğretmenlere göre bu maddeyi daha çok sorun olarak gördükleri ortaya çıkmıştır.

\section{Erkek Okulöncesi Öğretmeni için daha çok sorun:}

M18: Öğretmenin öğrencilerin kendilerinden korktuğunu hissetmesi. 31-40<41+. Yaş1 41+ olan öğretmenler ile yaşı 31-40 arasında olan öğretmenler arasında "Öğretmenin öğrencilerin kendilerinden korktuğunu hissetmesi" maddesinde anlamlı bir fark bulunmuş olup $(\mathrm{p}=0,014<0,05)$; yaşı 41'in üzerinde olan öğretmenler yaşı 30-40 arasında olan öğretmenler bu maddeyi erkek okul öncesi ögretmenlerinde daha çok sorun olarak gördükleri ortaya çıkmıştır.

\subsection{Medeni Durum Değişkenine Göre Elde Edilen Bulgular}

Öğretmenlerin medeni durumu evli ve bekâr olmak üzere iki kategoride ele alınmıştır. Anket maddelerinden elde edilen puan ortalamalarının medeni durum değişkenine göre farklılık gösterip göstermediğine ilişkin yapılan t-testi sonuçları Tablo 4.5 'te sunulmaktadır.

Tablo 4.5. Medeni Durum Değişkenine Göre Alınan Puanların t-testi Sonuçları

\begin{tabular}{|c|c|c|c|c|c|c|}
\hline & & $\mathrm{n}$ & $\overline{\mathbf{X}}$ & SS & $\mathrm{t}$ & $\mathrm{p}$ \\
\hline \multicolumn{7}{|c|}{ Okul öncesi eğitimde sorun olduğuna katılma } \\
\hline \multirow{2}{*}{ M24 } & Evli & 182 & 3,47 & 1,45154 & \multirow[t]{2}{*}{$-2,817$} & \multirow[t]{2}{*}{0,005} \\
\hline & Bekâr & 53 & 4,09 & 1,27497 & & \\
\hline \multicolumn{7}{|c|}{ Erkek okul öncesi öğretmeninin daha fazla sorun yaşadığına katılma } \\
\hline \multirow{2}{*}{ M9 } & Evli & 182 & 3,21 & 1,55774 & \multirow[t]{2}{*}{$-2,539$} & \multirow[t]{2}{*}{0,012} \\
\hline & Bekâr & 53 & 3,83 & 1,47721 & & \\
\hline \multirow{2}{*}{ M20 } & Evli & 182 & 2,97 & 1,46951 & \multirow[t]{2}{*}{$-1,987$} & \multirow[t]{2}{*}{0,048} \\
\hline & Bekâr & 53 & 3,43 & 1,55055 & & \\
\hline \multirow{2}{*}{ M34 } & Evli & 182 & 3,09 & 1,42862 & \multirow[t]{2}{*}{$-2,083$} & \multirow[t]{2}{*}{0,038} \\
\hline & Bekâr & 53 & 3,56 & 1,53810 & & \\
\hline
\end{tabular}

$\mathrm{p}<0,05$

\section{Okulöncesi öğretmeni için sorun:}

"Okullara görüşmeye genellikle kadın velilerin gelmesi maddesinde" (24.madde) evli ve bekar öğretmenler arasında anlamlı fark bulunmuş olup $(\mathrm{p}=0,005<0,05)$; bekar öğretmenlerin evli öğretmenlere göre bu maddeyi daha çok sorun olarak gördükleri ortaya çıkmıştır. [ $\overline{\mathbf{X}}=\operatorname{Bekar}(4,09)>$ Evli $(3,47)]$. 


\section{Erkek Okulöncesi Ö̆̆gretmeni için daha çok sorun:}

"Öğretmenlerin evrak yükünün fazla olması” maddesinde (M9) evli ve bekâr öğretmenler arasında anlamlı fark bulunmuş olup ( $\mathrm{p}=0,012<0,05)$; bekar öğretmenlerin evli öğretmenlere göre bu maddeyi erkek okul öncesi öğretmenlerinde daha çok sorun olarak gördükleri ortaya çıkmıştır. [ $\overline{\mathbf{X}}=$ Bekar $(3,83)>$ Evli $(3,21)]$.

"Devam zorunluğu olmaması nedeniyle velilerin esnek davranması" maddesinde (M20) evli ve bekar ögretmenler arasında anlamlı fark bulunmuş olup (p: 0,048<0,05); bekar öğretmenlerin evli öğretmenlere göre bu maddeyi erkek okul öncesi öğretmenlerinde daha çok sorun olarak gördükleri ortaya çıkmıştır. [ $\overline{\mathbf{X}}=$ Bekar $(3,43)>$ Evli $(2,97)]$.

"Öğretmenlerin özel eğitime gereksinimi olan öğrencilerle ilgili bilgisinin yetersizliği" maddesinde (34. Madde) evli ve bekar öğretmenler arasında anlamlı fark bulunmuş olup (p: $0,038<0,05$ ); bekar öğretmenlerin evli öğretmenlere göre bu maddeyi erkek okul öncesi öğretmenlerinde daha çok sorun olarak gördükleri ortaya çıkmıştır. [ $\overline{\mathbf{X}}=\operatorname{Bekar}(3,56)>$ Evli $(3,09)]$.

\subsection{Mezuniyet Durumu Değişkenine Göre Elde Edilen Bulgular}

Öğretmenlerin mezuniyet durumu Okul Öncesi Eğitim Fakültesi ve Diğer Eğitim Fakültesi olmak üzere iki kategoride ele alınmıştır. Anket maddelerinden elde edilen puan ortalamalarının mezuniyet durumu değişkenine göre farklılık gösterip göstermediğine ilişkin yapılan Man Whitney $U$ testi sonuçları Tablo 4.6'da sunulmaktadır.

Tablo 4.6. Mezuniyet Durum Değişkenine Göre Alınan Puanların Man Whitney U testi Sonuçları

\begin{tabular}{|c|c|c|c|c|c|c|}
\hline & & $\mathrm{n}$ & $\overline{\mathbf{X}}$ & SS & $\mathrm{Z}$ & $\mathrm{p}$ \\
\hline \multicolumn{7}{|c|}{ Okul öncesi eğitimde sorun olduğuna katılma } \\
\hline \multirow{2}{*}{ M4 } & Okul öncesi eğitim & 228 & 120,10 & 1,28 & $-2,460$ & ,014 \\
\hline & Diğer ĕgitim fakültesi & 8 & 72,88 & 1,88 & & \\
\hline \multicolumn{7}{|c|}{ Erkek okul öncesi öğretmeninin daha fazla sorun yaşadığına katılma } \\
\hline \multirow{2}{*}{ M11 } & Okul öncesi eğitim & 228 & 120,10 & 1,46 & $-2,041$ & 041 \\
\hline & Diğer eğitim fakültesi & 8 & 73,00 & 1,58 & & \\
\hline
\end{tabular}

\section{Okul Öncesi Öğretmeni için sorun:}

"Öğretmenlerin teneffüs ihtiyacını gidermesi için bir düzenleme olmaması" maddesinde (M4) öğretmenlerin mezuniyet durumuna göre anlamlı bir farkl1lı bulunmuş olup $(\mathrm{p}=0,014<0,05)$; okul öncesi eğitim fakültesinden mezun olan öğretmenler diğer eğitim fakültelerinden mezun olan öğretmenlere göre bu maddeyi daha çok sorun olarak gördükleri ortaya çıkmıştır. [ $\overline{\mathbf{X}}=$ Okul öncesi eğitim fakültesi $(120,10)>$ Diğer Eğitim Fakültesi $(72,88)]$.

\section{Erkek Okulöncesi Öğretmeni için daha çok sorun:}

"Öğretmenlere yardımcı olacak personel yetersizliği” maddesinde (M11) öğretmenlerin mezuniyet durumuna göre anlamlı bir farkl1lık bulunmuş olup $(\mathrm{p}=0,041<0,05)$; okul öncesi eğitim fakültesinden mezun olan öğretmenler diğer eğitim fakültelerinden mezun olan öğretmenlere göre bu maddeyi erek okul öncesi öğretmenlerin de daha çok sorun olarak gördükleri ortaya çıkmıştır. [ $\overline{\mathbf{X}}$ : Okul öncesi eğitim fakültesi $(120,10)>$ Diğer Eğitim Fakültesi $(73,00)]$.

\section{6. Şube Değişkenine Göre Elde Edilen Bulgular}

Öğretmenlerin görüşleri okutulan şubeye göre; 4 yaş, 5 yaş ve $4-5$ yaş olarak üç kategoride ele alınmıştır. Anket maddelerinden elde edilen puan ortalamalarının okutulan şube değişkenine göre farlılık gösterip göstermediğine ilişkin yapılan ANOVA sonuçları Tablo 4.7'de sunulmaktadır. 
Tablo 4.7. Şube Değişkenine Göre Alınan Puanların ANOVA testi Sonuçları

\begin{tabular}{|c|c|c|c|c|c|c|c|}
\hline & & Kareler toplamı & $\mathrm{df}$ & Ort. karesi & $\mathrm{F}$ & $\mathrm{p}$ & Fark \\
\hline Okul & incesi eğitimde & run olduğuna katıl & & & & & \\
\hline & Gruplar aras1 & 27,923 & 2 & 13,962 & 5,939 & 003 & $(3<4),(2<4)$ \\
\hline M1 & Gruplar içi & 547,755 & 233 & 2,351 & & & \\
\hline & Toplam & 575,678 & 235 & & & & \\
\hline & Gruplar aras1 & 15,209 & 2 & 7,605 & 3,432 & ,034 & $2<4$ \\
\hline M2 & Gruplar içi & 516,261 & 233 & 2,216 & & & \\
\hline & Toplam & 531,470 & 235 & & & & \\
\hline & Gruplar aras1 & 28,757 & 2 & 14,378 & 6,805 & ,001 & $(3<4),(2<4)$ \\
\hline M3 & Gruplar içi & 492,277 & 233 & 2,113 & & & \\
\hline & Toplam & 521,034 & 235 & & & & \\
\hline & Gruplar aras1 & 29,429 & 2 & 14,715 & 7,068 & ,001 & $(3<4),(2<4)$ \\
\hline M5 & Gruplar içi & 485,058 & 233 & 2,082 & & & \\
\hline & Toplam & 514,487 & 235 & & & & \\
\hline & Gruplar aras1 & 13,206 & 2 & 6,603 & 3,172 & 044 & $2<4$ \\
\hline M6 & Gruplar içi & 485,014 & 233 & 2,082 & & & \\
\hline & Toplam & 498,220 & 235 & & & & \\
\hline & Gruplar aras1 & 18,996 & 2 & 9,498 & 5,002 & ,007 & $(2<4),(3<4)$ \\
\hline M15 & Gruplar içi & 442,410 & 233 & 1,899 & & & \\
\hline & Toplam & 461,407 & 235 & & & & \\
\hline & Gruplar aras1 & 12,561 & 2 & 6,280 & 3,378 & ,036 & $2<4$ \\
\hline M16 & Gruplar içi & 433,168 & 233 & 1,859 & & & \\
\hline & Toplam & 445,729 & 235 & & & & \\
\hline & Gruplar arası & 12,666 & 2 & 6,333 & 3,384 & ,036 & $2<4$ \\
\hline M31 & Gruplar içi & 435,991 & 233 & 1,871 & & & \\
\hline & Toplam & 448,657 & 235 & & & & \\
\hline & Gruplar aras1 & 12,298 & 2 & 6,149 & 3,731 & ,025 & $2<4$ \\
\hline M33 & Gruplar içi & 384,007 & 233 & 1,648 & & & \\
\hline & Toplam & 396,305 & 235 & & & & \\
\hline Erke & okul öncesi ög & meninin daha fazla & yaşad & 1ğına katılma & & & \\
\hline & Gruplar aras1 & 21,494 & 2 & 10,747 & 4,386 & ,013 & $2<4$ \\
\hline M1 & Gruplar içi & 570,896 & 233 & 2,450 & & & \\
\hline & Toplam & 592,390 & 235 & & & & \\
\hline M3 & Gruplar aras 1 & 19,793 & 2 & 9,896 & 3,999 & ,020 & $2<4$ \\
\hline & Gruplar içi & 576,614 & 233 & 2,475 & & & \\
\hline & Toplam & 596,407 & 235 & & & & \\
\hline M5 & Gruplar aras1 & 13,764 & 2 & 6,882 & 3,506 & 032 & $2<4$ \\
\hline & Gruplar içi & 457,422 & 233 & 1,963 & & & \\
\hline & Toplam & 471,186 & 235 & & & & \\
\hline M10 & Gruplar aras 1 & 17,466 & 2 & 8,733 & 4,107 & ,018 & $2<3$ \\
\hline & Gruplar içi & 495,483 & 233 & 2,127 & & & \\
\hline & Toplam & 512,949 & 235 & & & & \\
\hline M31 & Gruplar aras1 & 12,902 & 2 & 6,451 & 3,502 & ,032 & $2<3$ \\
\hline & Gruplar içi & 429,234 & 233 & 1,842 & & & \\
\hline & Toplam & 442,136 & 235 & & & & \\
\hline M32 & Gruplar aras1 & 10,635 & 2 & 5,318 & 3,315 & ,038 & $2<3$ \\
\hline & Gruplar içi & 373,750 & 233 & 1,604 & & & \\
\hline & Toplam & 384,386 & 235 & & & & \\
\hline M33 & Gruplar aras1 & 11,586 & 2 & 5,793 & 3,412 & ,035 & $2<3$ \\
\hline & Gruplar içi & 395,613 & 233 & 1,698 & & & \\
\hline & Toplam & 407,199 & 235 & & & & \\
\hline
\end{tabular}




\section{Okul Öncesi Öğretmeni için sorun:}

M1: Okulumuzdaki kişisel ihtiyaçlara yönelik fiziksel koşulların (lavabo vb.) yeterli olmaması. 4 yaş $<4-5$ yaş, 5 yaş < 4-5 yaş. 4 yaş grubu öğretmenleri ile 4-5 yaş birlikte eğitim gören öğrenci grubu öğretmenleri arasında ve 5 yaş grubu öğretmenleri ile 4-5 yaş birlikte eğitim gören öğrenci grubu öğretmenleri arasında "Okulumuzdaki kişisel ihtiyaçlara yönelik fiziksel koşulların (lavabo vb.) yeterli olmaması" maddesinde anlamlı bir fark bulunmuş olup $(\mathrm{p}=0,003<0,05)$; Tukey HSD ve Scheffe analiz sonuçlarına göre; $4-5$ yaş birlikte eğitim gören öğrenci grubu öğretmenleri, 4 yaş ve 5 yaş grubunda çalışan öğretmenlere göre bu maddeyi daha çok sorun olarak gördükleri ortaya çıkmıştır.

M2: Sınıf, yemekhane ve ortak kullanım alanlarının fiziksel koşullarının yeterli olmaması. 4 yaş $<4-5$ yaş. 4 yaş grubu öğretmenleri ile 4-5 yaş birlikte eğitim gören öğrenci grubu öğretmenleri arasında "Sınıf, yemekhane ve ortak kullanım alanlarının fiziksel koşullarının yeterli olmaması" maddesinde anlamlı bir fark bulunmuş olup ( $\mathrm{p}=0,034<0,05)$; Tukey HSD ve Scheffe analiz sonuçlarına göre; 4-5 yaş birlikte eğitim gören öğrenci grubu öğretmenleri, 4 yaş grubunda çalışan öğretmenlere göre bu maddeyi daha çok sorun olarak gördükleri ortaya çıkmıştır.

M3: Ortak kullanılan sınıf ve alanların temizliğinin öğretmenlerce yapılması. 4 yaş $<4-5$ yaş, 5 yaş $<$ 4-5 yaş. 4 yaş grubu öğretmenleri ile 4-5 yaş birlikte eğitim gören öğrenci grubu öğretmenleri arasında ve 5 yaş grubu öğretmenleri ile $4-5$ yaş birlikte eğitim gören öğrenci grubu öğretmenleri arasında "Ortak kullanılan sınıf ve alanların temizliğinin öğretmenlerce yapılması" maddesinde anlamlı bir fark bulunmuş olup $(\mathrm{p}=0,001<0,05)$; Tukey HSD ve Scheffe analiz sonuçlarına göre; 4-5 yaş birlikte eğitim gören öğrenci grubu öğretmenleri, 4 yaş ve 5 yaş grubunda çalışan öğretmenlere göre bu maddeyi daha çok sorun olarak gördükleri ortaya çıkmıştır.

M5: Okul yöneticilerinin okul öncesi eğitimle ilgili bilgisinin yeterli olmaması. 4 yaş $<4-5$ yaş, 5 yaş $<4-5$ yaş. 4 yaş grubu öğretmenleri ile 4-5 yaş birlikte eğitim gören öğrenci grubu öğretmenleri arasında ve 5 yaş grubu öğretmenleri ile 4-5 yaş birlikte eğitim gören öğrenci grubu öğretmenleri arasında "Okul yöneticilerinin okul öncesi eğitimle ilgili bilgisinin yeterli olmaması" maddesinde anlamlı bir fark bulunmuş olup ( $\mathrm{p}=0,001<0,05)$; Tukey HSD ve Scheffe analiz sonuçlarına göre; 4-5 yaş birlikte eğitim gören öğrenci grubu öğretmenleri, 4 yaş ve 5 yaş grubunda çalışan öğretmenlere göre bu maddeyi daha çok sorun olarak gördükleri ortaya çıkmıştır.

M6: Okul yöneticilerinin okul öncesi eğitimi öğretmenlerine olumsuz önyargıyla yaklaşması. 4 yaş < 4-5 yaş. 4 yaş grubu öğretmenleri ile 4-5 yaş birlikte eğitim gören öğrenci grubu öğretmenleri arasında "Okul yöneticilerinin okul öncesi eğitimi öğretmenlerine olumsuz önyargıyla yaklaşması" maddesinde anlamlı bir fark bulunmuş olup ( $\mathrm{p}=0,044<0,05)$; Tukey HSD ve Scheffe analiz sonuçlarına göre; 4-5 yaş birlikte eğitim gören öğrenci grubu öğretmenleri, 4 yaş grubunda çalışan öğretmenlere göre bu maddeyi daha çok sorun olarak gördükleri ortaya çıkmıştır.

M15: Sinıflardaki öğrenci sayılarının fazlalığı. 4 yaş $<4-5$ yaş, 5 yaş $<4-5$ yaş. 4 yaş grubu ögretmenleri ile 4-5 yaş birlikte eğitim gören öğrenci grubu öğretmenleri arasında ve 5 yaş grubu öğretmenleri ile 4-5 yaş birlikte eğitim gören öğrenci grubu öğretmenleri arasında "Sinıflardaki öğrenci sayılarının fazlalı̆̆ı" maddesinde anlamlı bir fark bulunmuş olup $(\mathrm{p}=0,007<0,05)$; Tukey HSD ve Scheffe analiz sonuçlarına göre; 4-5 yaş birlikte eğitim gören öğrenci grubu öğretmenleri, 4 yaş ve 5 yaş grubunda çalışan öğretmenlere göre bu maddeyi daha çok sorun olarak gördükleri ortaya çıkmıştır.

M16: İkili öğretimde öğrencilerin sabah ve öğleye dengesiz dağılımı. 4 yaş $<4-5$ yaş. 4 yaş grubu öğretmenleri ile 4-5 yaş birlikte eğitim gören öğrenci grubu öğretmenleri arasında "İkili öğretimde öğrencilerin sabah ve öğleye dengesiz dağ 1 lımı" maddesinde anlamlı bir fark bulunmuş olup $(p=0,036<0,05)$; Tukey HSD ve Scheffe analiz sonuçlarına göre; $4-5$ yaş birlikte eğitim gören öğrenci grubu öğretmenleri, 4 yaş grubunda çalışan öğretmenlere göre bu maddeyi daha çok sorun olarak gördükleri ortaya çıkmıştır.

M31: Eğitim programının ihtiyacı karşılamaması. 4 yaş $<4-5$ yaş. 4 yaş grubu öğretmenleri ile 4-5 yaş birlikte eğitim gören öğrenci grubu öğretmenleri arasında "Eğitim programının ihtiyacı karşılamaması" maddesinde anlamlı bir fark bulunmuş olup $(\mathrm{p}=0,036<0,05)$; Tukey HSD ve Scheffe 
analiz sonuçlarına göre; 4-5 yaş birlikte eğitim gören öğrenci grubu öğretmenleri, 4 yaş grubunda çalışan öğretmenlere göre bu maddeyi daha çok sorun olarak gördükleri ortaya çıkmıştır.

M33: Eğitim programının öğretmenlerce farklı uygulanması. 4 yaş $<4-5$ yaş. 4 yaş grubu öğretmenleri ile 4-5 yaş birlikte eğitim gören öğrenci grubu öğretmenleri arasında "Eğitim programının öğretmenlerce farklı uygulanması" maddesinde anlamlı bir fark bulunmuş olup $(p=0,025<0,05)$; Tukey HSD ve Scheffe analiz sonuçlarına göre; 4-5 yaş birlikte eğitim gören öğrenci grubu öğretmenleri, 4 yaş grubunda çalışan öğretmenlere göre bu maddeyi daha çok sorun olarak gördükleri ortaya çıkmıştır.

\section{Erkek Okul Öncesi Öğretmeni için daha çok sorun:}

M1: Okulumuzdaki kişisel ihtiyaçlara yönelik fiziksel koşulların (lavabo vb.) yeterli olmaması. 4 yaş $<4-5$ yaş. 4 yaş grubu öğretmenleri ile 4-5 yaş birlikte eğitim gören öğrenci grubu öğretmenleri arasında "Okulumuzdaki kişisel ihtiyaçlara yönelik fiziksel koşulların (lavabo vb.) yeterli olmaması" maddesinde anlamlı bir fark bulunmuş olup $(\mathrm{p}=0,013<0,05)$; Tukey HSD ve Scheffe analiz sonuçlarına göre; 4-5 yaş birlikte eğitim gören öğrenci grubunda çalışan öğretmenlerin, 4 yaş grubunda çalışan öğretmenlere göre bu maddeyi erkek okul öncesi öğretmenlerinde kadın öğretmenlere göre daha çok sorun olarak gördükleri ortaya çıkmıştır.

M3: Ortak kullanılan sınıf ve alanların temizliğinin öğretmenlerce yapılması. 4 yaş $<4-5$ yaş. 4 yaş grubu öğretmenleri ile 4-5 yaş birlikte eğitim gören öğrenci grubu öğretmenleri arasında "Ortak kullanılan sınıf ve alanların temizliğinin öğretmenlerce yapılması" maddesinde anlamlı bir fark bulunmuş olup ( $\mathrm{p}=0,020<0,05)$; Tukey HSD ve Scheffe analiz sonuçlarına göre; $4-5$ yaş birlikte eğitim gören öğrenci grubunda çalışan öğretmenlerin, 4 yaş grubunda çalışan öğretmenlere göre bu maddeyi erkek okul öncesi öğretmenlerinde kadın öğretmenlere göre daha çok sorun olarak gördükleri ortaya çıkmıştır.

M5: Okul yöneticilerinin okul öncesi eğitimle ilgili bilgisinin yeterli olmaması. 4 yaş $<4-5$ yaş. 4 yaş grubu öğretmenleri ile 4-5 yaş birlikte eğitim gören öğrenci grubu öğretmenleri arasında "Okul yöneticilerinin okul öncesi eğitimle ilgili bilgisinin yeterli olmaması" maddesinde anlamlı bir fark bulunmuş olup ( $\mathrm{p}=0,032<0,05)$; Tukey HSD ve Scheffe analiz sonuçlarına göre; $4-5$ yaş birlikte eğitim gören öğrenci grubunda çalışan öğretmenlerin, 4 yaş grubunda çalışan öğretmenlere göre bu maddeyi erkek okul öncesi öğretmenlerinde kadın öğretmenlere göre daha çok sorun olarak gördükleri ortaya çıkmıştır.

M10: Yöneticilerin okul öncesi eğitimin amaçları dışında beklentilerinin olması. 4 yaş $<5$ yaş. 4 yaş grubu öğretmenleri ile 5 yaş grubu öğretmenleri arasında "Yöneticilerin okul öncesi eğitimin amaçları dışında beklentilerinin olması" maddesinde anlamlı bir fark bulunmuş olup ( $\mathrm{p}=0,018<0,05)$; Tukey HSD ve Scheffe analiz sonuçlarına göre; 5 yaş grubunda çalışan öğretmenlerin, 4 yaş grubunda çalışan öğretmenlere göre bu maddeyi erkek okul öncesi öğretmenlerinde kadın öğretmenlere göre daha çok sorun olarak gördükleri ortaya çıkmıştır.

M31: Eğitim programının ihtiyacı karşılamaması. 4 yaş $<5$ yaş. 4 yaş grubu öğretmenleri ile 5 yaş grubu öğretmenleri arasında "Eğitim programının ihtiyacı karşılamaması" maddesinde anlamlı bir fark bulunmuş olup $(\mathrm{p}=0,032<0,05)$; Tukey HSD ve Scheffe analiz sonuçlarına göre; 5 yaş grubunda çalışan öğretmenlerin, 4 yaş grubunda çalışan öğretmenlere göre bu maddeyi erkek okul öncesi öğretmenlerinde kadın öğretmenlere göre daha çok sorun olarak gördükleri ortaya çıkmıştır.

M32: Kullanılan öğretim yöntemlerinin amaçlara uygun olmayışı. 4 yaş $<5$ yaş. 4 yaş grubu öğretmenleri ile 5 yaş grubu öğretmenleri arasında "Kullanılan öğretim yöntemlerinin amaçlara uygun olmayışı" maddesinde anlamlı bir fark bulunmuş olup $(\mathrm{p}=0,038<0,05)$; Tukey HSD ve Scheffe analiz sonuçlarına göre; 5 yaş grubunda çalışan öğretmenlerin, 4 yaş grubunda çalışan öğretmenlere göre bu maddeyi erkek okul öncesi öğretmenlerinde kadın öğretmenlere göre daha çok sorun olarak gördükleri ortaya çıkmıştır.

M33: Eğitim programının öğretmenlerce farklı uygulanması. 4 yaş $<5$ yaş. 4 yaş grubu öğretmenleri ile 5 yaş grubu öğretmenleri arasında "Eğitim programının öğretmenlerce farklı uygulanması" maddesinde anlaml 1 bir fark bulunmuş olup $(\mathrm{p}=0,035<0,05)$; Tukey HSD ve Scheffe analiz 
sonuçlarına göre; 5 yaş grubunda çalışan öğretmenlerin, 4 yaş grubunda çalışan öğretmenlere göre bu maddeyi erkek okul öncesi ögretmenlerinde kadın öğretmenlere göre daha çok sorun olarak gördükleri ortaya çıkmıştır.

\subsection{Okul türü değişsenine göre elde edilen bulgular}

Öğretmenlerin çalıştıkları okul türü devlete bağlı kamu kurumlarından olan anaokulları ile ilkokul, ortaokul, liselerin bünyesinde bulunan anasınıfları olarak iki kategoride ele alınmıştır. Anket maddelerinden elde edilen puan ortalamalarının okul türü değişkenine göre farklılık gösterip göstermediğine ilişkin yapılan t-testi sonuçları Tablo 4.8'de sunulmaktadır.

Tablo 4.8. Okul Türü Değişkenine Göre Alınan Puanların t-testi Sonuçları

\begin{tabular}{|c|c|c|c|c|c|c|}
\hline & & $\mathrm{n}$ & $\overline{\mathbf{X}}$ & SS & $\mathrm{t}$ & $\mathrm{p}$ \\
\hline \multicolumn{7}{|c|}{ Okul öncesi eğitimde sorun olduğuna katılma } \\
\hline \multirow{2}{*}{ M1 } & Anaokulu & 116 & 2,20 & 1,51237 & $-4,105$ & 0,000 \\
\hline & Anasınıfi & 120 & 3,01 & 1,51731 & & \\
\hline \multirow{2}{*}{ M2 } & Anaokulu & 116 & 2,56 & 1,50529 & $-3,703$ & 0,000 \\
\hline & Anasınıfi & 120 & 3,26 & 1,42448 & & \\
\hline \multirow{2}{*}{ M3 } & Anaokulu & 116 & 1,84 & 1,36161 & $-3,643$ & 0,000 \\
\hline & Anasinıfi & 120 & 2,53 & 1,53356 & & \\
\hline \multirow{2}{*}{ M5 } & Anaokulu & 116 & 2,13 & 1,44401 & $-4,326$ & 0,000 \\
\hline & Anasinıfi & 120 & 2,94 & 1,41002 & & \\
\hline \multirow{2}{*}{ M6 } & Anaokulu & 116 & 2,13 & 1,45002 & $-2,011$ & 0,046 \\
\hline & Anasınıfi & 120 & 2,51 & 1,44352 & & \\
\hline \multirow{2}{*}{ M8 } & Anaokulu & 116 & 2,83 & 1,65736 & $-4,950$ & 0,000 \\
\hline & Anasınıfi & 120 & 3,85 & 1,51350 & & \\
\hline \multirow{2}{*}{ M9 } & Anaokulu & 116 & 3,77 & 1,36469 & $-2,037$ & 0,043 \\
\hline & Anasınıfi & 120 & 4,10 & 1,13608 & & \\
\hline \multirow{2}{*}{ M15 } & Anaokulu & 116 & 3,51 & 1,57967 & $-2,968$ & 0,003 \\
\hline & Anasinıfi & 120 & 4,05 & 1,15118 & & \\
\hline \multirow{2}{*}{ M30 } & Anaokulu & 116 & 3,45 & 1,34741 & $-2,270$ & 0,024 \\
\hline & Anasınifi & 120 & 3,83 & 1,19757 & & \\
\hline
\end{tabular}

Erkek okul öncesi öğretmeninin daha fazla sorun yaşadığına katılma

\begin{tabular}{lllllll}
\multirow{2}{*}{ M1 } & Anaokulu & 116 & 2,18 & 1,53177 & $-3,518$ & 0,001 \\
& Anasinifi & 120 & 2,90 & 1,56860 & & \\
\hline \multirow{2}{*}{ M2 } & Anaokulu & 116 & 2,26 & 1,45278 & $-3,847$ & 0,000 \\
& Anasinifi & 120 & 3,00 & 1,47244 & & \\
\hline \multirow{2}{*}{ M3 } & Anaokulu & 116 & 1,90 & 1,43241 & $-3,729$ & 0,000 \\
& Anasinifi & 120 & 2,65 & 1,65766 & & \\
\hline \multirow{2}{*}{ M5 } & Anaokulu & 116 & 2,06 & 1,39393 & $-3,310$ & 0,001 \\
& Anasinifi & 120 & 2,66 & 1,38013 & & \\
\multirow{2}{*}{ M6 } & Anaokulu & 116 & 2,21 & 1,56486 & $-2,109$ & 0,036 \\
& Anasinifi & 120 & 2,63 & 1,47775 & & \\
\multirow{2}{*}{ M8 } & Anaokulu & 116 & 2,47 & 1,64429 & $-4,135$ & 0,000 \\
& Anasinifi & 120 & 3,38 & 1,73051 & & \\
\multirow{2}{*}{ M9 } & Anaokulu & 116 & 3,15 & 1,58033 & $-2,004$ & 0,046 \\
& Anasinifi & 120 & 3,55 & 1,51072 & & \\
\hline \multirow{2}{*}{ M10 } & Anaokulu & 116 & 2,39 & 1,52018 & $-2,024$ & 0,044 \\
& Anasinifi & 120 & 2,78 & 1,41530 & & \\
\hline \multirow{2}{*}{ M11 } & Anaokulu & 116 & 3,47 & 1,59052 & $-2,719$ & 0,007
\end{tabular}




\begin{tabular}{lllllll} 
& Anasinifi & 120 & 3,99 & 1,32523 & & \\
\multirow{2}{*}{ M15 } & Anaokulu & 116 & 3,02 & 1,67572 & $-2,352$ & 0,020 \\
& Anasinifi & 120 & 3,50 & 1,47241 & & \\
\multirow{2}{*}{ M24 } & Anaokulu & 116 & 3,81 & 1,43808 & $-2,039$ & 0,043 \\
& Anasinifi & 120 & 4,15 & 1,10499 & & \\
\multirow{2}{*}{ M28 } & Anaokulu & 116 & 4,03 & 1,40143 & $-2,019$ & 0,045 \\
& Anasinifi & 120 & 4,36 & 1,11471 & & \\
\hline
\end{tabular}

$\mathrm{p}<0,05$

\section{Okulöncesi öğretmeni için sorun:}

"Okulumuzdaki kişisel ihtiyaçlara yönelik fiziksel koşulların (lavabo vb.) yeterli olmaması" maddesinde (M1) anaokulunda çalışan öğretmenler ile anasınıfında çalışan öğretmenler arasında anlamlı fark bulunmuş olup $(\mathrm{p}=0,00<0,05)$; anasınıfinda çalışan öğretmenlerin anaokulunda çalışan öğretmenlere göre bu maddeyi daha çok sorun olarak gördükleri ortaya çıkmıştır. $[\overline{\mathbf{X}}=$ Anasınıfı $(3,01)>$ Anaokulu $(2,20)]$.

"Sınıf, yemekhane ve ortak kullanım alanlarının fiziksel koşullarının yeterli olmaması" maddesinde (M2) anaokulunda çalışan öğretmenler ile anasınıfında çalışan öğretmenler arasında anlamlı fark bulunmuş olup $(\mathrm{p}=0,00<0,05)$; anasınıfında çalışan öğretmenlerin anaokulunda çalışan öğretmenlere göre bu maddeyi daha çok sorun olarak gördükleri ortaya çıkmıştır. [ $\overline{\mathbf{X}}=$ Anasınıfı $(3,26)>$ Anaokulu $(2,56)]$.

“Ortak kullanılan sınıf ve alanların temizliğinin öğretmenlerce yapılması” maddesinde (M3) anaokulunda çalışan öğretmenler ile anasınıfında çalışan öğretmenler arasında anlamlı fark bulunmuş olup ( $\mathrm{p}=0,00<0,05)$; anasınıfında çalışan öğretmenlerin anaokulunda çalışan öğretmenlere göre bu maddeyi daha çok sorun olarak gördükleri ortaya çıkmıştır. [ $\overline{\mathbf{X}}=$ Anasınıfı $(2,53)>$ Anaokulu $(1,84)]$.

“Okul yöneticilerinin okul öncesi eğitimle ilgili bilgisinin yeterli olmaması" maddesinde (M5) anaokulunda çalışan öğretmenler ile anasınıfinda çalışan öğretmenler arasında anlamlı fark bulunmuş olup $(\mathrm{p}=0,00<0,05)$; anasınıfında çalışan öğretmenlerin anaokulunda çalışan öğretmenlere göre bu maddeyi daha çok sorun olarak gördükleri ortaya çıkmıştır. [ $\overline{\mathbf{X}}=\operatorname{Anasınıfı}(2,94)>$ Anaokulu $(2,13)]$.

“Okul yöneticilerinin okul öncesi eğitimi öğretmenlerine olumsuz önyargıyla yaklaşması” maddesinde (M6) anaokulunda çalışan öğretmenler ile anasınıfında çalışan öğretmenler arasında anlamlı fark bulunmuş olup $(\mathrm{p}=0,046<0,05)$; anasınıfında çalışan öğretmenlerin anaokulunda çalışan öğretmenlere göre bu maddeyi daha çok sorun olarak gördükleri ortaya çıkmıştır. [ $\overline{\mathbf{X}}=$ Anasınıfı $(2,51)>$ Anaokulu $(2,13)]$.

"Öğretmenlere öğrencilerden okul adına para toplatılması" maddesinde (M8) anaokulunda çalışan öğretmenler ile anasınıfinda çalışan öğretmenler arasında anlamlı fark bulunmuş olup $(p=0,00<0,05)$; anasınıfında çalıșan öğretmenlerin anaokulunda çalıșan öğretmenlere göre bu maddeyi daha çok sorun olarak gördükleri ortaya çıkmıştır. [ $\overline{\mathbf{X}}=$ Anasınıfı $(3,85)>$ Anaokulu $(2,83)]$.

“Okul Öğretmenlerin evrak yükünün fazla olması” maddesinde (M9) anaokulunda çalışan öğretmenler ile anasınıfinda çalışan öğretmenler arasında anlamlı fark bulunmuş olup $(\mathrm{p}=0,043<0,05)$; anasınıfında çalışan öğretmenlerin anaokulunda çalışan öğretmenlere göre bu maddeyi daha çok sorun olarak gördükleri ortaya çıkmıştır. [ $\overline{\mathbf{X}}=$ Anasınıfı $(4,10)>$ Anaokulu $(3,77)]$.

"Sınıflardaki öğrenci sayılarının fazlalı̆̆ı" maddesinde (M15) anaokulunda çalışan öğretmenler ile anasınıfında çalışan öğretmenler arasında anlamlı fark bulunmuş olup ( $\mathrm{p}=0,003<0,05)$; anasınıfında çalışan öğretmenlerin anaokulunda çalışan öğretmenlere göre bu maddeyi daha çok sorun olarak gördükleri ortaya çıkmıştır. [ $\overline{\mathbf{X}}=$ Anasınıfı $(4,05)>$ Anaokulu $(3,51)]$.

"Eğitim öğretim materyalinin yetersizliği”" maddesinde (M30) anaokulunda çalışan öğretmenler ile anasınıfında çalışan öğretmenler arasında anlamlı fark bulunmuş olup $(\mathrm{p}=0,024<0,05)$; anasınıfında çalışan öğretmenlerin anaokulunda çalışan öğretmenlere göre bu maddeyi daha çok sorun olarak gördükleri ortaya çıkmıştır. ( $\overline{\mathbf{X}}=$ Anasınıfı $(3,83)>$ Anaokulu $(3,45)]$. 


\section{Erkek Okulöncesi Ö̆̆gretmeni için daha çok sorun:}

"Okulumuzdaki kişisel ihtiyaçlara yönelik fiziksel koşulların (lavabo vb.) yeterli olmaması" maddesinde (M1) anaokulunda çalışan öğretmenler ile anasınıfinda çalışan öğretmenler arasında anlamlı fark bulunmuş olup $(\mathrm{p}=0,001<0,05)$; anasınıfinda çalışan öğretmenlerin anaokulunda çalışan öğretmenlere göre bu maddeyi erkek okul öncesi öğretmenlerinde daha çok sorun olarak gördükleri ortaya çıkmıştır. [ $\overline{\mathbf{X}}=$ Anasınıfı $(2,90)>$ Anaokulu $(2,18)]$.

"Sınıf, yemekhane ve ortak kullanım alanlarının fiziksel koşullarının yeterli olmaması" maddesinde (M2) anaokulunda çalışan öğretmenler ile anasınıfinda çalışan öğretmenler arasında anlamlı fark bulunmuş olup $(\mathrm{p}=0,00<0,05)$; anasınıfinda çalışan öğretmenlerin anaokulunda çalışan öğretmenlere göre bu maddeyi erkek okul öncesi öğretmenlerinde daha çok sorun olarak gördükleri ortaya çıkmıştır. $[\overline{\mathbf{X}}=$ Anasinıfi $(3,00)>$ Anaokulu $(2,26)]$.

"Ortak kullanılan sınıf ve alanların temizliğinin öğretmenlerce yapılması" maddesinde (M3) anaokulunda çalışan öğretmenler ile anasınıfında çalışan öğretmenler arasında anlamlı fark bulunmuş olup $(\mathrm{p}=0,00<0,05)$; anasınıfında çalışan öğretmenlerin anaokulunda çalışan öğretmenlere göre bu maddeyi erkek okul öncesi öğretmenlerinde daha çok sorun olarak gördükleri ortaya çıkmıştır. $[\overline{\mathbf{X}}=$ Anasinifi $(2,65)>$ Anaokulu $(1,90)]$.

"Okul yöneticilerinin okul öncesi eğitimle ilgili bilgisinin yeterli olmaması" maddesinde (M5) anaokulunda çalışan öğretmenler ile anasınıfinda çalışan öğretmenler arasında anlamlı fark bulunmuş olup $(\mathrm{p}=0,001<0,05)$; anasınıfinda çalışan öğretmenlerin anaokulunda çalışan öğretmenlere göre bu maddeyi erkek okul öncesi öğretmenlerinde daha çok sorun olarak gördükleri ortaya çıkmıştır. ( $\overline{\mathbf{X}}=$ Anasinifi $(2,66)>$ Anaokulu $(2,06)]$.

"Okul yöneticilerinin okul öncesi eğitimi öğretmenlerine olumsuz önyargıyla yaklaşması" maddesinde (M6) anaokulunda çalışan öğretmenler ile anasınıfinda çalışan öğretmenler arasında anlamlı fark bulunmuş olup $(\mathrm{p}=0,036<0,05)$; anasınıfında çalışan öğretmenlerin anaokulunda çalışan öğretmenlere göre bu maddeyi erkek okul öncesi öğretmenlerinde daha çok sorun olarak gördükleri ortaya çıkmıştır. $[\overline{\mathbf{X}}=$ Anasinifi $(2,63)>$ Anaokulu $(2,21)]$.

“Öğretmenlere öğrencilerden okul adına para toplatılması" maddesinde (M8) anaokulunda çalışan ögretmenler ile anasınıfında çalışan öğretmenler arasında anlamlı fark bulunmuş olup $(p=0,00<0,05)$; anasınıfinda çalışan öğretmenlerin anaokulunda çalışan öğretmenlere göre bu maddeyi erkek okul öncesi öğretmenlerinde daha çok sorun olarak gördükleri ortaya çıkmıştır. $[\overline{\mathbf{X}}=$ Anasınıfı $(3,38)>$ Anaokulu $(2,47)]$.

“Öğretmenlerin evrak yükünün fazla olması” maddesinde (M9) anaokulunda çalışan öğretmenler ile anasınıfında çalışan öğretmenler arasında anlamlı fark bulunmuş olup $(\mathrm{p}=0,046<0,05)$; anasınıfında çalışan öğretmenlerin anaokulunda çalışan öğretmenlere göre bu maddeyi erkek okul öncesi öğretmenlerinde daha çok sorun olarak gördükleri ortaya çıkmıştır. [ $\overline{\mathbf{X}}=$ Anasınıfı $(3,55)>$ Anaokulu $(3,15)]$.

"Yöneticilerin okul öncesi eğitimin amaçları dışında beklentilerinin olması" maddesinde (M10) anaokulunda çalışan öğretmenler ile anasınıfında çalışan öğretmenler arasında anlamlı fark bulunmuş olup $(\mathrm{p}=0,044<0,05)$; anasınıfında çalışan öğretmenlerin anaokulunda çalışan öğretmenlere göre bu maddeyi erkek okul öncesi öğretmenlerinde daha çok sorun olarak gördükleri ortaya çıkmıştır. $[\overline{\mathbf{X}}=$ Anasinıfi $(2,78)>$ Anaokulu $(2,39)]$.

"Öğretmenlere yardımcı olacak personel yetersizliği” maddesinde (M11) anaokulunda çalışan öğretmenler ile anasınıfında çalışan öğretmenler arasında anlamlı fark bulunmuş olup (p: 0,007<0,05); anasınıfında çalışan öğretmenlerin anaokulunda çalışan öğretmenlere göre bu maddeyi erkek okul öncesi öğretmenlerinde daha çok sorun olarak gördükleri ortaya çıkmıştır. [ $\overline{\mathbf{X}}=$ Anasınıfı $(3,99)>$ Anaokulu $(3,47)]$.

"Sınıflardaki öğrenci sayılarının fazlalığı" maddesinde (M15) anaokulunda çalışan öğretmenler ile anasınıfında çalışan öğretmenler arasında anlamlı fark bulunmuş olup ( $\mathrm{p}=0,020<0,05)$; anasınıfında çalışan öğretmenlerin anaokulunda çalışan öğretmenlere göre bu maddeyi erkek okul öncesi 
öğretmenlerinde daha çok sorun olarak gördükleri ortaya çıkmıştır. [ $\overline{\mathbf{X}}=$ Anasınıfı $(3,50)>$ Anaokulu $(3,02)]$.

"Okullara görüşmeye genellikle kadın velilerin gelmesi" maddesinde (M24) anaokulunda çalışan öğretmenler ile anasınıfında çalışan öğretmenler arasında anlamlı fark bulunmuş olup ( $p=0,043<0,05)$; anasınıfinda çalışan öğretmenlerin anaokulunda çalışan öğretmenlere göre bu maddeyi erkek okul öncesi öğretmenlerinde daha çok sorun olarak gördükleri ortaya çıkmıştır. $[\overline{\mathbf{X}}=$ Anasınıfı $(4,15)>$ Anaokulu (3,81)].

"Velilerin okul öncesi öğretmenliğini kadın işi olarak görmeleri” maddesinde (28.madde) anaokulunda çalışan öğretmenler ile anasınıfinda çalışan öğretmenler arasında anlamlı fark bulunmuş olup $(p=0,045<0,05)$; anasınıfinda çalışan öğretmenlerin anaokulunda çalışan öğretmenlere göre bu maddeyi erkek okul öncesi öğretmenlerinde daha çok sorun olarak gördükleri ortaya çıkmıştır. [ $\overline{\mathbf{X}}=$ Anasinifi $(4,36)>$ Anaokulu $(4,03)]$.

\section{TARTIŞMA VE SONUÇ}

\subsection{Tartışma}

Okul öncesi eğitim kurumlarında çalışan okul öncesi öğretmenlerinin okul öncesi eğitimde var olan sorunların erkek okul öncesi öğretmenlerince ne düzeyde yaşandığını tespit etmek amacıyla yapılan araştırmanın bulguları dikkate alındığında öğretmenler genel olarak; velilerin öğretmenler arasında kıyaslama yapmalarını, velilerin okul öncesi eğitimi bakım hizmeti olarak görmeleri ve velilerin okul öncesi öğretmenliğini kadın işi olarak görmeleri maddelerinin erkek okulöncesi öğretmenlerinde daha çok sorun teşkil ettiği bulgusuna ulaşılmıştır. Bu doğrultuda; toplumumuzda hala okul öncesi öğretmenliğinin bir kadın mesleği olarak görüldüğü ve bu yüzden erkek okul öncesi öğretmenlerine eğitim yönünden güvenilmediği sonucuna ulaş1labilir. Yine toplumumuzun okul öncesi eğitimin amacını ve gerekliliğini kavrayamadığı günümüz şartlarında bile okul öncesi eğitimi sadece bakım hizmeti olarak gördükleri sonucuna ulaşabiliriz. $\mathrm{Bu}$ ön yargılar erkek öğretmenlerin işlerine odaklanmasını güçleştirmekte ve okul öncesi eğitimin gerekliliklerini yerine getirmelerinde zorlanmalarına neden olmaktadır.

Gülçiçek'in (2017) yapmış olduğu araştırmaya göre; katılımcılar erkek öğretmenlerin anne olmama durumunu dezavantaj olarak görmüşler ve okul öncesi öğretmenliğinin kadın işi olduğu kanısına varmışlardır. Bu sonuçlar ile bu araştırmada da elde edilen bulgular benzerlik göstermektedir. Yine aynı araştırmada katılımcılar erkek öğretmenlerin çocuklar üzerinde daha fazla kontrolü olduğunu ve erkeklerin anne olmama durumunu onlar için bir avantaj olarak görmüşler ve erkek öğretmenlerin öğretmenlik yaparken bazı avantajlarının olabileceğini ve bu durumda okul öncesi öğretmenliği içerisinde erkek öğretmenlere de yer verilmesi kanısına varmışlardır. Bu durum bir nevi toplumda bazı açılardan bakıldığında erkek öğretmenlerin okul öncesi eğitimde faydalı olabilecekleri sonucu çıkmıştır. Fakat bu sonuç araştırma bulgularımızla örtüşmemektedir.

Demirtaş, Demir ve Demir'in (2014) yapmış olduğu araştırmaya göre; katılımcılardan bazıları erkek öğretmenlerin çocuklarının öz bakım ihtiyaçlarını gideremeyecekleri kanısına varmışlar. Bu yüzden erkek öğretmenin zorluk yaşayacağı düşüncesini savunmuşlardır. Bu araştırmada da velilerin okul öncesi eğitimi bakım hizmeti olarak görmeleri ve bu doğrultuda erkek öğretmenlerin bu hizmeti gerçekleştirirken zorlanacakları algısı devam etmiş ve bu durum araştırma bulgularımızla da örtüşmektedir.

Cameron'ın (2001) yapmış olduğu araştırmaya göre; okul öncesi eğitimin, aileler tarafından çocuk bakımı ve beslenmesi olarak algılaması ve bu mesleği kadınların yapmasının daha uygun olduğu sonucuna ulaşılması yaptığımız araştırma bulgusuyla örtüşmektedir.

Sarı ve Basarır'ın (2016) yapmış olduğu araştırmaya göre; okul öncesi eğitimin kadının doğasına daha uygun olduğu ve okul öncesi eğitiminin çocuk bakımıyla alakalı olduğu düşünülerek kadın ögretmenlerin daha çok tercih edildiği sonucuna ulaşmış. Bu sonuçta yaptığımız araştırma bulgularıyla örtüşmüştür.

Yalçın, Macun ve Yalçın’nın (2017) yapmış oldukları araştırmada da kadın öğretmenlerin annelik iç güdüsü ve çocukla daha iyi iletişim kuracakları inancından dolayı erkek öğretmenlere güvenin daha az 
olduğu kanısına varılmış, bu doğrultuda yaptığımız araştırma bulgusuyla bu araştırmanında örtüştüğü görülmüştür.

Ergen ve Günay'ın (2019) yapmış oldukları araştırmada, öğretmenlerin saygı gereksinimleriyle ilişkilendirilen bazı maddelerdeki ifadelere erkek öğretmenlerin daha fazla katıldıkları ortaya çıkmıştır. Bu bulgu, mevcut araştırmanın bulgularıyla örtüşmektedir.

\subsection{Sonuç}

Araştırma sonuçlarına göre; öğretmenler genel olarak, teneffüs saatlerinin olmamasını bir sorun olarak görmüşlerdir. Okul öncesi öğretmenliği haricindeki diğer branşlarda görev yapan öğretmenlerin belirli bir ders saatinden sonra teneffüs yapıyor olmaları ama okul öncesi öğretmenlerinin 5 dakika da olsa dinlenme firsatı bulamaması öğretmenler açısından sorun olarak görüldüğü belirlenmiştir. İkili eğitim yapan okul öncesi eğitim kurumlarında özellikle öğlenci devredeki gruplara öğrenci sayısının aşırı yüklenmesi ve sabahçı gruplara göre öğrenci sayılarının fazla olma durumu öğretmenler açısından adaletsizlik olarak görülmüș ve sorun olarak tespit edilmiştir. Okul öncesi eğitim kurumlarındaki velilerin okul öncesi eğitimi bakım hizmeti olarak görmesi velilerin eğitime karşı bakış açılarını göstermekte bu durumu da öğretmenler sorun olarak gördükleri sonucuna ulaşılmıştır. Yine velilerin öğretmenler arasında kıyaslama yapmasını okul öncesi öğretmenleri genel olarak sorun olduğunu belirtmişlerdir. Öğretmenlerin birbirleri arasında kıyaslanması öğretmenlerin kendilerinde baskı ortamı yaratılmasına yol açmasını sağladığını bu durumunda öğretmenlerde huzursuzluğa yol açtığı sonucuna ulaşılabilir. Velilerin okul öncesi eğitimi kadın işi olarak görmeleri de okul öncesi öğretmenleri tarafindan sorun olarak görüldüğü sonucuna ulaşılmıştır. Aslında bu durum okul öncesi hizmetini bakım hizmeti olarak görme sorunuyla benzerlikler içermektedir. İçinde yaşadığımız toplum genel olarak çocuk bakım hizmetini kadınların daha iyi yapacağını düşünmekte bu durumda da küçük çocuklarla kadın öğretmenlerin daha iyi ilgileneceğini düşünmektedirler. Okul öncesi eğitimi kadın işi olarak görmelerine bu düşüncenin sebep olduğu söylenebilir. Velilerin okul öncesi eğitim hakkındaki yetersiz bilgisi araştırma sonucunda yüksek düzeyde sorun olarak görüldüğü sonucuna ulaşılmıştır. Velilerin genel olarak okul öncesi eğitime bakış açısı ve eğitim hakkındaki bilgilerinin yetersizliği bu sorunların ortaya çıkmasına etken olduğu söylenebilir.

Araştırma sonunda öğretmenler, erkek okul öncesi öğretmenlerin kadın öğretmenlere göre daha çok sorun yaşadıklarını düşündükleri sorunlar olarak; velilerin öğretmenler arasında kıyaslama yapması, velilerin okul öncesi eğitimi bakım hizmeti olarak görmesi ve velilerin okul öncesi öğretmenliğini kadın işi olarak görmesi durumları ortaya çıkmıştır. Bu sonuca göre toplum tarafından okul öncesi öğretmenliğinin kadın işi olarak görülmesi çocuk bakıcılığı görevini erkek öğretmenlerin yapamayacağının düşünülmesi durumu okul öncesi eğitimin veliler tarafından yeterince anlaşılamadığını, eğitimin amaçlarının yeterince kavranamadığı sonucuna ulaşılabilir. Tabi bu durumda eğitimin kavranması için Bakanlık tarafından veli bilinçlendirme programları hazırlanmalı, toplumda gerekli farkındalığı oluşturmak için okul öncesi eğitimin amaç ve hedefleri sosyal ortamlarda, kamu spotları halinde TV'de sık sık yer verilebilir. Bunlar haricinde eğitici seminerler düzenlenebilir. Ayrıca, bu doğrultuda gerekli bilgilendirmeler toplum nezdinde yapılabilir.

Okul öncesi eğitimin toplumda kadın işi olarak görülmesi de toplum olarak bu eğitime karşı nasıl bilinçsiz bakış açımızın olduğunu göstermektedir. Oysa ki yurt dışı araştırmalarında genel olarak erkek rolünün bu eğitimin içinde bulunması çocuklar açısından önemli olduğu dile getirilmektedir. $\mathrm{Bu}$ yüzden Bakanlık tarafından bir politika oluşturulup erkek öğretmenleri bu eğitime çekebilmek için çeşitli teşvik uygulamalarına gidilebilir.

\section{Bilgilendirme / Acknowledgement:}

Yazarlar așağıdaki billgillendirmeleri yapmaktadırlar:

1- Araştırmacıların katkı oranı beyanı buraya yazılmalıdır.

2- Bu makale birinci yazarın Mayıs 2019'da Mersin Üniversitesi Eğitim Bilimleri Enstitüsüne sunduğu Dönem Projesi çalışmasına dayanmaktadır

3- Makalenin yazarları arasında çıkar çatışması bulunmamaktadır

4- Araştırma verileri 2019 Mart ayı içinde toplanıp yorumlanmıştır.

5- Bu makalede araştırma ve yayın etiğine uyulmuştur. 


\section{KAYNAKÇA}

Ağgül Yalçın, F. ve Yalçın, M. (2018). Okul öncesi öğretmenlerin okul öncesi eğitimin sorunlarıyla ilgili görüşleri: Ağr1 ili örneği. İlköğretim Online, 17(1), 367-383.

Argon, T. ve Akkaya, M. (2008). Ebeveynlerin okul öncesi eğitime ve okul öncesi eğitim kurumlarına yönelik görüşleri. Kastamonu Eğitim Dergisi, 16, 413-430.

Akman, B., Baydemir, G., Akyol, T., Arslan, A.Ç. ve Kükütçü, S.K. (2011) Okulöncesi öğretmenlerinin sınıfta karşılaştıkları sorun davranışlara ilişkin düşünceleri. E-Journal of New World Sciences Academy Education Sciences, 6(2), 1306-3111.

Başturan, C. (2018). Devlet ve özel okul öncesi eğitim kurumlarında görev yapan ögretmenlerin mesleki sorun tanımlarının incelenmesi. Yayımlanmamış yüksek lisans tezi, İstanbul Okan Üniversitesi Sağlık Bilimleri Enstitüsü, İstanbul.

Cameron, C. (2001). Promise or problem? a review of the literature on males working in early childhood services. Gender, Work and Organization, 8(4), 430-439.

Çetinkaya, B. (2010). Türkiye'de okul öncesi eğitim ve sorunları. Yayımlanmamış yüksek lisans tezi, Beykent Üniversitesi Sosyal Bilimler Enstitüsü, İstanbul.

d'Arcy, C. (2004). Males studying and working in early childhood education: Advantages, barriers, challenges and examples of successful strategies to recruit, retain and support men. NSW: Community Services and Health Industry Skills Council.

Demir, M. K. ve Arı, E. (2013). Öğretmen sorunları: Çanakkale ili örneği. Ondokuz Mayls Üniversitesi Eğitim Fakültesi Dergisi, 32(1), 107-126.

Demircan Aydın, Z. (2017). Öğretmen ve yöneticilerin okul öncesi eğitimi değerlendirmeleri ve bu alanda yaşanılan yönetimsel sorunlar. Yayımlanmamış yüksek lisans tezi, Okan Üniversitesi Sosyal Bilimler Enstitüsü, İstanbul.

Dee, T. S. (2006). The why chromosome: How a teacher's gender affects boys and girls. Education Next, 6(4), 68-75.

Demirtaş, H., Demir, H. C. ve Demir, M., (2014) Türkiye’deki anaokullarında erkek öğretmen algısı. International Journal of Early Childhood Education Research, 3(7), 60-95.

Elicker, J. (2002). More men in early childhood education? Why? Young children, 57(6), 50-54.

Ergen, H. ve Günay, T. (2019). Okul öncesi öğretmenlerinin çalıştı̆̆1 kurumlarda yaşadığ1 yönetsel sorunlarla ilgili görüşleri. Uşak Üniversitesi Eğitim Araştırmaları Dergisi, 5(2), 63-89.

Gülçiçek, T., (2017). Ebeveynlerin erkek okul öncesi ögretmenleri ile ilgili algılarının incelenmesi. Yayımlanmamış yüksek lisans tezi, Orta Doğu Teknik Üniversitesi Eğitim Bilimleri Enstitüsü, Ankara.

Gündoğan, A. (2002). Okul öncesi eğitim kurumlarında çalışan öğretmenlerin karşılaştıkları sorunlar (Denizli ili örneği). Yayımlanmamış yüksek lisans tezi, Pamukkale Üniversitesi Sosyal Bilimler Enstitüsü, Denizli.

Jones, J. (2009). Briefing paper: men in early childhood education. New Zealand Journal of Teachers' Work, 6(1), 28-34.

Karakaya, İ. (2012). Bilimsel araştırma yöntemleri. A. Tanrı̈ğen (Ed.) Bilimsel araştırma yöntemleri içinde. 57-86. Ankara: Anı.

Kaya, N., (2013). Okul öncesi eğitim öğretmenlerinin yaşadığı sorunlar ve hizmet içi eğitim ihtiyaçları araştırma raporu. 12 Mart 2019 tarihinde https://www.academia.edu/6954387 adresinden erişildi. 
Kök, M., Küçükoğlu, A., Tuğluk, M. N. ve Koçyiğit, S., (2007). Okul öncesi eğitimin sorunlarına ilişkin öğretmen görüşleri (Erzurum ili örneği). Atatürk Üniversitesi Kazım Karabekir Eğitim Fakültesi Dergisi, 16, 160-171.

Milli Eğitim Temel Kanunu. (1973, 24 Haziran). Resmî Gazete (Say1: 1739).

Okutan, N. (2003). Erken çocukluk eğitimi politikaları: Yaygınlaşma, yönetişim ve yapılar toplantısı raporu. Ankara: M.E.B., AÇEV, UNICEF ve Eğitim Reformu Girişimi.

Özen, Ş. (2008). Okul öncesi eğitim ve aile: Anne ve babalartn okul öncesi eğitimden beklentileri (Kars ili örneği). Yayımlanmamış yüksek lisans tezi, Kafkas Üniversitesi Sosyal Bilimler Enstitüsü, Kars.

Öztürk, M. (2012). The influences of male early childhood education teachers on parental involvement. Unpublished doctoral dissertation, University of Texas at San Antonio.

Russo, S., Feder, T. (2001). A preliminary investigation of barriers faced by male early childhood preservice teachers. Early Child Development and Care, 170(1), 57-75.

Sak, R., (2005). Erkek okul öncesi öğretmenlerin göreve başladıklarında karşılaştıkları durumlar ve bu ögretmenlerin velilerinin erkek okul öncesi öğretmenleri hakkındaki düşünceleri. Yayımlanmamış yüksek lisans tezi, Gazi Üniversitesi Eğitim Bilimleri Enstitüsü, Ankara.

Sarı, M., \& Başarır, F. (2016). Analyzing teachers' perceptions of "female teacher" and "male teacher" within traditional gender roles. International Journal of Education and Research, 4(3), 205-224.

Şimşek, Z. C. ve İvrendi, A. (2014). Ebeveynlerin okul öncesi eğitim kurumlarından beklentileri. Hacettepe Üniversitesi Eğitim Fakültesi Dergisi, 29(2), 240-254.

Taner, M. ve Başal, H.A., (2005). Farklı sosyoekonomik düzeylerde okul öncesi eğitimi alan ve almayan ilköğretim birinci sınıf öğrencilerinin dil gelişimlerinin cinsiyete göre karşılaştırılması. Uludağ Üniversitesi Ĕgitim Fakültesi Dergisi, 18(2), 395-420.

Yalçın, F., A., Yalçın, M. ve Macun, B. (2017). Okul öncesi öğretmenlerinin okul öncesi eğitimde öğretmen cinsiyeti ile ilgili görüşleri. Bayburt Eğitim Fakültesi Dergisi, 12(24), 693-710.

Zaimoğlu Öztürk, F., Kaya, N. ve Durmaz, E., (2015). Okul öncesi öğretmenlerinin görev sürecinde yaşadıkları eğitimsel sorunlar ve çözüm önerileri. Karadeniz Sosyal Bilimler Dergisi, Hüseyin Hüsnü Tekışık Özel Sayısı, 2(7), 67-93.

Zembat, R. (2005). Okul öncesi eğitimde nitelik: güncel konular. İstanbul: Morpa Kültür Yayınları.

Zembat, R. (2012). Okul öncesi öğretmenlerinin okul yöneticisi, meslektaşları ve aileler bağlamında algıladıkları çatışma durumlarının incelenmesi. Eğitim ve Bilim, 37(163), 203-215. 